A RCHIWA, BIBLIOTEKI

I MUZEA KOŚCIELNE 112 (2019)

https://doi.org.10.31743/abmk.2019.112.19

EDGAR SUKIENNIK* - WARSZAWA

\title{
BIBLIOGRAFIA SANKTUARIUM MATKI JEDNOŚCI CHRZEŚCIJAN W ŚWIĘTEJ LIPCE ZA LATA 1618-2018
}

\begin{abstract}
Streszczenie
Sanktuarium maryjne w Świętej Lipce na Mazurach to jedno z najbardziej znanych miejsc pielgrzymkowych w Polsce. Od czasów średniowiecza przybywają tu pielgrzymi z Polski i z krajów sąsiednich, aby modlić się przed słynącym łaskami wizerunkiem Matki Bożej oraz słuchać koncertów muzycznych, które wykonywane są na imponujących organach barokowych. W 2018 roku sanktuarium przeżywało trzy ważne rocznice: 400-lecie oddania Świętej Lipki pod opiekę króla polskiego Zygmunta III Wazy i jego następców, 125-lecie ukończenia świętolipskiej szkoły muzycznej przez Feliksa Nowowiejskiego oraz 50-lecie koronacji obrazu Matki Bożej Swiętolipskiej przez prymasa Polski kard. Stefana Wyszyńskiego oraz metropolitę krakowskiego kard. Karola Wojtyłę. Uroczysty jubileusz stworzył okazję do wielu podsumowań w zakresie stanu badań historycznych nad dziejami kościoła i klasztoru jezuitów. Prezentowana bibliografia usiłuje zebrać to, co już wiadomo na temat sanktuarium, oraz próbuje zasugerować obszary badawcze, które jeszcze oczekują na swoich dziejopisów.
\end{abstract}

Słowa kluczowe: Święta Lipka; jezuici; kult maryjny; bibliografia; badania historyczne

\section{Święta Lipka w historiografii polskiej i zagranicznej}

Znane sanktuarium maryjne, nazywane powszechnie „Częstochową Północy", usytuowane jest niemal na historycznej granicy Warmii i Mazur, nad jeziorem Dejnowa, przy drodze prowadzącej z Kętrzyna do Reszla. Prężnie działający ośrodek życia religijnego rozwinął się tutaj w związku z kultem słynącej łaskami figurki Matki Bożej, która odbierała cześć od XIV wieku. Na temat początków Świętej Lipki powstało wiele legend, podań i interpretacji, których nie trzeba w tym miejscu przytaczać, gdyż stanowią one odrębny problem badawczy. Nato-

* Edgar Sukiennik - dr historii; Muzeum Jana Pawła II i Prymasa Wyszyńskiego; Warszawa; e-mail: edgar.sukiennik@wp.pl

https://orcid.org/0000-0002-7294-9894 
miast należy zauważyć, że kult figurki dynamicznie się rozwijał i zapoczątkował powstanie w tym miejscu kaplicy, która dała początek późniejszemu sanktuarium. Jego funkcjonowanie zostało brutalnie przerwane w czasie dominacji protestantyzmu w Prusach. W pierwszej połowie XVI wieku protestanci zniszczyli figurkę i zabronili katolikom pielgrzymowania do kaplicy.

W okresie restauracji katolicyzmu po Soborze Trydenckim ośrodek kultu maryjnego zaczął się odradzać. Doniosłą rolę w tym procesie odegrał Stefan Sadorski, dworzanin królewski, który w 1617 roku wykupił Świętą Lipkę z rąk Ottona von Groebena, a w roku następnym oddał ją pod opiekę króla polskiego Zygmunta III Wazy i jego następców. W 1632 roku pieczę nad tym miejscem roztoczyli ojcowie jezuici, którzy cieszyli się wówczas dużym poważaniem w całym Kościele. Zakonnicy pojawili się tutaj dzięki przychylności S. Sadorskiego, który pragnął zapewnić miejscu świętemu godziwą obsługę duszpasterską i widział w tej roli przede wszystkim duchowych synów św. Ignacego Loyoli. W latach 80. XVII wieku jezuici rozpoczęli wznoszenie nowej świątyni w stylu barokowym. W ciągu kilkunastu lat na placu stanął emporowy kościół z majestatyczną fasadą, która odznaczała się wyjątkowym kunsztem. W centralnym miejscu świątyni zawisł obraz Matki Bożej z Dzieciątkiem pędzla Bartłomieja Pensa z 1640 roku. W tym czasie Święta Lipka była już popularnym miejscem pielgrzymkowym, do którego przybywali pątnicy z Polski, Litwy, Prus, a nawet bardziej odległych krajów Europy zachodniej i południowej, o czym świadczą zachowane do dziś relacje jezuity Tomasza Clagiusa ${ }^{1}$. Okazały kościół, usytuowany dosłownie wśród jezior i lasów, pozostaje jednym z najchętniej odwiedzanych ośrodków pielgrzymkowych i turystycznych w Polsce. Architektura sakralna została tutaj doskonale wkomponowana w urzekający krajobraz naturalny, co niedawno trafnie wyraził kustosz świętolipskiego sanktuarium, o. dr Aleksander Jacyniak, gdy wspomniał o ,pięknie ludzkiego tworzenia wpisanym w piękno Boskiego stworzenia"2.

Miejsce $\mathrm{z}$ tak bogatą i różnorodną przeszłością, a przy tym będące ważnym ośrodkiem życia religijnego Warmii i Mazur, nie mogło pozostać niezauważone przez historyków Kościoła i miłośników historii regionalnej. Pragnęli oni poznawać jego dzieje i upowszechniać wyniki swoich dociekań. Próby opisania dziejów Świętej Lipki można odnaleźć już w XVII wieku, w związku z szerzącymi się informacjami o cudownych uzdrowieniach, których mieli doświadczać pielgrzymi modlący się za wstawiennictwem Matki Bożej. W tym kontekście należy odczytywać prace dwóch duchownych: ks. Michała Ciaritiusa (1626) i wspomnianego już jezuity Tomasza Clagiusa vel Klagi (1659), które ukazały się drukiem i dały okazję do propagowania sanktuarium ${ }^{3}$. Oba dzieła stanowią podstawę dla badań nad rozwojem kultu maryjnego w Świętej Lipce, choć wymagają biegłej znajomości łaciny. Dużą wartość poznawczą ma niemieckojęzyczna praca ks. Augustyna Kolberga pt. Geschichte der Heiligenlinde, która została opublikowana na

${ }^{1}$ Zob. T. Clagius, Linda Mariana sive de B. Virgine Lindensi libri V, Coloniae 1659.

${ }^{2}$ A. Jacyniak, Chcę stużyć Matce Bożej Świętolipskiej [rozmowa z Franciszkiem Mrozem], „Nasza Arka”, (2018) nr 5 (209), s. 13.

${ }^{3}$ M.F. Ciaritius, B. V. M. Lindensis. Vetustissimum et religiossimum in Prussia Sacellum Beatissimae Virginis Mariae sacrum, prodigiis divinis clarissimum, Brunsbergae 1626. 
łamach czasopisma historycznego „Zeitschrift für die Geschichte und Altertumskunde Ermlands" w 1866 roku $^{4}$. Autor wnikliwie przebadał archiwum parafialne w Świętej Lipce, dzięki czemu wprowadził do obiegu naukowego wiele informacji dotychczas nieznanych. Późniejsze prace XIX i XX-wiecznych uczonych, m.in. Antona Ulbricha ${ }^{5}$, Georga Lühra ${ }^{6}$, Mariana Borzyszkowskiego ${ }^{7}$ i bpa Jana Obłąka ${ }^{8}$, wprawdzie poszerzyły zakres wiedzy o dziejach kościoła świętolipskiego, ale były daleko od ich kompleksowego ujęcia.

W szerokim wachlarzu publikacji poświęconych Świętej Lipce nie mogło zabraknąć tematów związanych z dziełami sztuki i ich konserwacji na przestrzeni ostatnich dziesięcioleci. W tym kontekście warto przytoczyć opracowanie Elizy Buszko odnośnie problemów konserwatorskich sanktuarium świętolipskiego, ze szczególnym uwzględnieniem zabytkowych krużganków ${ }^{9}$. Na wartość obiektów zabytkowych i konieczność poddawania ich zabiegom konserwatorskim zwrócili uwagę także Michał Czapski i Maria Wanat-Zakrzewska w artykułach traktujących o konserwacji kościoła, krużganków i rzeźb kamiennych, które występują na terenie sanktuarium w dużej liczbie ${ }^{10}$.

Święta Lipka długo czekała na monografię historyczną, która uwzględniłaby różne aspekty funkcjonowania sanktuarium, parafii i klasztoru na przestrzeni dziejów. Naprzeciw tym oczekiwaniom wyszedł o. Jerzy Paszenda, jezuita, który opublikował obszerną, liczącą prawie 400 stron, publikację pt. Święta Lipka monografia (Kraków 2008). Zawarł w niej nie tylko informacje znane z poprzednich opracowań, lecz także poszerzył je o wiadomości pozyskane z akt Centralnego Archiwum Zakonu Jezuitów w Rzymie oraz dokumentacji przechowywanej w Archiwum Archidiecezji Warmińskiej w Olsztynie. W tym dziele warto zwrócić uwagę na następujące tematy: początki sanktuarium, najstarsze źródła pisane i drukowane do historii kultu maryjnego, ruch pielgrzymkowy na przestrzeni dziejów, walory artystyczne kościoła i otaczających go krużganków, powstanie parafii świętolipskiej oraz imponujące dzieła sztuki, które zdobią ściany i sklepienia kościoła. Obszerna monografia ks. J. Paszendy pozostaje fundamentalnym źródłem informacji o tym, co już wiemy na temat sanktuarium, a co jeszcze pozostało do rozpoznania, ewentualnie do uzupełnienia.

${ }^{4}$ A. Kolberg, Geschichte der Heiligelinde, „Zeitschrift für die Geschichte und Altertumskunde Ermlands" 1866, Bd 3, s. 28-138; 435-520.

${ }^{5}$ A. Ulbrich, Die Wallfahrtskirche in Heiligelinde. Ein Beitrag zur Kunstgeschichte des XVII. und XVIII. Jahrhunderts in Ostpreussen, Strassburg 1901.

${ }^{6}$ G. Lühr, Die Jesuiten von Rösel und Heiligelinde, ,Zeitschrift für die Geschichte und Altertumskunde Ermlands", 20 (1919) nr 20, s. 753-800.

7 M. Borzyszkowski, Święta Lipka w latach 1920-1940, „Studia Warmińskie”, 32 (1995) s. $103-116$.

${ }^{8}$ J. Obłąk, Święta Lipka, Olsztyn 1975; wyd. 2, Olsztyn 1982.

${ }^{9}$ E. Buszko, Problemy konserwatorskie sanktuarium w Świętej Lipce, w: Święta Lipka: perła na pograniczu ziem, kultur $i$ wyznań, red. A. Jacyniak, Warszawa 2008, s. 176-198.

${ }^{10}$ M. Czapski, Zabezpieczenie krużganków w Świętej Lipce, „Inżynieria i Budownictwo” 16 (1959), nr 1, s. 1-6; M. Wanat-Zakrzewska, Konserwacja rzeźby kamiennej barokowego kościoła w Świętej Lipce w latach 1982-1987, „Rocznik Olsztyński” 17 (1997), s. 125-141. 
Monografia znanego jezuity wprawdzie odpowiedziała na wiele postulatów badawczych, jednak nie wyczerpała tematu. Poszczególne zagadnienia wymagały rozwinięcia przez kolejnych naukowców. Problem ten został poruszony w referatach wygłoszonych przez specjalistów podczas pierwszej części sympozjum: Święta Lipka: perła na pograniczu ziem, kultur i wyznań, które odbyło się w klasztorze świętolipskim w 2008 roku. Dla przykładu można wspomnieć tekst autorstwa prof. Stanisława Achremczyka o znaczeniu Świętej Lipki w okresie I Rzeczypospolitej ${ }^{11}$. Historiografię sanktuarium wzbogacił również artykuł ks. prof. Andrzeja Kopiczki poświęcony negatywnemu stosunkowi władz komunistycznych do uroczystości koronacyjnych w $1968 \mathrm{roku}^{12}$. Genezę najstarszych pieśni świętolipskich omówił ks. Sławomir Ropiak ${ }^{13}$. Funkcjonowaniu barokowych organów przyjrzał się Rafał Sulima ${ }^{14}$, najstarsze zachowane druki zaś, z których korzystali świętolipscy jezuici, ustaliła Lidia Zielińska ${ }^{15}$. Referaty ogłoszone drukiem w publikacji okolicznościowej odkryły wiele nieznanych epizodów z dziejów omawianego sanktuarium.

W gronie historyków zajmujących się dziejami Świętej Lipki nie można pominąć prof. Janusza Hochleitnera. Niedawno zmarły wykładowca Uniwersytetu Warmińsko-Mazurskiego w Olsztynie i wicedyrektor Muzeum Zamkowego w Malborku pozostawił po sobie m.in. publikacje dotyczące ruchu pielgrzymkowego w czasach nowożytnych oraz funkcjonowania kapliczek przydrożnych, będących ważną częścią lokalnego krajobrazu ${ }^{16}$. Niebagatelnym przyczynkiem do dziejów Świętej Lipki są publikacje naukowe i popularno-naukowe, które wychodzą spod pióra lokalnego etnografa - Tadeusza Korowaja. Historyk powiatu kętrzyńskiego jest twórcą licznych opracowań zarówno $\mathrm{w}$ formie publikacji zwartych, jak również krótkich artykułów, ukazujących się regularnie na łamach czasopisma parafialnego „U stóp Świętolipskiej Matki”. Teksty jego autorstwa znacząco porządkują i uzupełniają stan badań nad dziejami Świętej Lipki i pozostałych miejscowości należących do tej rozległej parafii.

Pogłębieniu badań nad dziejami świętolipskiego sanktuarium sprzyjał kończący się rok 2018, czyli okres ważnych jubileuszy: 400-lecia oddania Swiętej Lipki pod opiekę króla polskiego, 125-lecia ukończenia tutejszej szkoły muzycznej przez wybitnego kompozytora Feliksa Nowowiejskiego oraz 50-lecia koronacji obrazu Matki Bożej Świętolipskiej przez prymasa Polski kard. Stefana Wyszyńskiego oraz metropolitę krakowskiego kard. Karola Wojtyłę (11 VIII 1968). Ob-

${ }^{11}$ S. Achremczyk, Znaczenie Świętej Lipki w Rzeczpospolitej szlacheckiej, w: Święta Lipka: perta na pograniczu, s. 98-117.

${ }^{12}$ A. Kopiczko, Władze partyjno-państwowe wobec koronacji obrazu Matki Bożej w Świętej Lipce, w: Święta Lipka: perła na pograniczu, s. 245-300.

${ }^{13}$ S. Ropiak, Pieśni świętolipskie, w: Święta Lipka: perła na pograniczu, s. 147-166.

${ }^{14}$ R. Sulima, Organy świętolipskie, w: Święta Lipka: perła na pograniczu, s. 131-146.

${ }^{15}$ L. Zielińska, Księgozbiór starodruków świętolipskich w Bibliotece Bobolanum $w$ Warszawie, w: Święta Lipka: perta na pograniczu, s. 88-97.

${ }^{16}$ J. Hochleitner, Religijność Mazurów manifestowana w Świętej Lipce (XVI-XX w.), w: Mniejszość $i$ większość. Relacje kulturowe na pograniczach, cz. 1, red. Paweł Pietnoczka, Olsztyn 2016, s. 175-192; tenże, Przydrożne pomniki kultu religijnego Świętej Lipki i okolic, „Studia Angerburgica", 2 (2006) s. 78-91. 
chody jubileuszu rozpoczęły się drugą częścią sympozjum popularnonaukowego pt. Święta Lipka: perła na pograniczu ziem, kultur $i$ wyznań, które odbyło się 17 marca 2018 roku w świętolipskim domu pielgrzyma. Podczas konferencji wystąpiło 11 prelegentów z Warmii, Mazur, Mazowsza i Małopolski. Zaprezentowali oni wyniki swoich badań nad dziejami sanktuarium, parafii i klasztoru. Według zapowiedzi organizatorów teksty wystąpień mają ukazać się drukiem w okolicznościowej publikacji.

Kulminacja obchodów jubileuszowych nastąpiła 11 sierpnia 2018 roku, czyli dokładnie w 50. rocznicę koronacji słynącego łaskami wizerunku Maryi z Dzieciątkiem. W uroczystej sumie na placu przed bazyliką wzięli udział przedstawiciele Episkopatu Polski, władz samorządowych oraz pielgrzymi, którzy mimo deszczowej pogody dość licznie przybyli na centralną uroczystość. W roku świętowania jubileuszu sanktuarium świętolipskie dostąpiło jeszcze jednego, szczególnego zaszczytu, jakim było wpisanie go na listę pomników historii. To najwyższa forma wyróżnienia, jaką dysponuje państwo polskie, aby uhonorować obiekty o szczególnej wartości historycznej. Święta Lipka znalazła się zatem w elitarnym gronie niespełna 100 obiektów zabytkowych obdarzonych tym tytułem w całym kraju. Można się spodziewać, że obfitość przełomowych wydarzeń z życia sanktuarium zachęci historyków do podejmowania kolejnych zagadnień związanych z dziedzictwem świętolipskim.

\section{Wstęp}

Proponowana poniżej bibliografia przedmiotowa stanowi próbę zebrania możliwie jak największej liczby pozycji naukowych i popularno-naukowych, które zostały wprowadzone do obiegu naukowego w formie publikacji. Bibliografia obejmuje lata 1618-2018, czyli od momentu oddania Świętej Lipki pod opiekę króla polskiego Zygmunta III Wazy i jego następców, aż do uroczystości 400 . rocznicy tamtego wydarzenia oraz 50. rocznicy koronacji obrazu Matki Bożej Świętolipskiej. Zgromadzony materiał dotyczy historii sanktuarium świętolipskiego, kultu Najświętszej Maryi Panny, ruchu pielgrzymkowego na przestrzeni dziejów, pracy duszpasterskiej ojców jezuitów, wartości zabytkowej zespołu kościelno-klasztornego, mecenatu artystycznego fundatorów i dobrodziejów kościoła, życia codziennego mieszkańców parafii, nie pomijając obecności innowierców na omawianym terenie. W zamierzeniu opracowującego poniższy spis bibliograficzny ma służyć pomocą tym badaczom, którzy zechcą omówić w swoich pracach różne aspekty dziejów Świętej Lipki, jak również miłośnikom historii regionalnej, którzy pragną zgłębiać literaturę przedmiotu i poznać lepiej swoją małą ojczyznę. W celu ułatwienia poszukiwań zaproponowano podział na kilkanaście działów, do których przyporządkowano tytuły poszczególnych opracowań. Ze względu na objętość materiału ograniczono się do wyszczególnienia jedynie tych prac, które ukazały się drukiem jako publikacje zwarte bądź jako teksty w wydawnictwach ciągłych. Pominięto natomiast prace dyplomowe, które nie zostały wprowadzone do obiegu naukowego w ramach publikacji. Mają one wartościowy wkład w badania historyczne nad dziejami świętolipskiego sanktuarium, o czym świadczy choćby fakt, że były cytowane w publikacjach niektórych naukowców, niemniej jednak dostęp do nich jest znikomy lub poważnie utrudniony. 


\section{BIBLIOGRAFIA PRZEDMIOTOWA SANKTUARIUM ŚWIĘTOLIPSKIEGO}

\section{Hasła ogólne w encyklopediach, słownikach i bibliografiach}

1. Grzebień Ludwik, Podstawowa bibliografia do dziejów Towarzystwa Jezusowego w Polsce, t. 1, Kraków 2009, s. 353-357. [Bibliografia przedmiotowa Świętej Lipki]

2. Heiligelinde, w: Brockhaus Enzyklopädie in 24 Bänden, t. 9, Manheim 1997, s. 622 .

3. Heilige Linde, w: Jesuiten-Lexikon, red. L. Koch, Paderborn 1934, s. 779.

4. Paszenda Jerzy, Święta Lipka, w: Encyklopedia katolicka, t. 19, red. E. Gigilewicz, Lublin 2013, s. 386-387.

5. Sanktuaria w Polsce, red. K.K. Czapliński, Katowice 2001, s. 110-111.

6. Święta Lipka, w: Atlas zabytków architektury w Polsce, red. H. Faryna-Paszkiewicz, R. Pasieczny, Warszawa 2001, s. 63.

7. Święta Lipka, w: Brockhaus Enzyklopädie in 24 Bänden, t. 21, Manheim 1993, s. 51.

8. Święta Lipka, w: Encyklopedia Popularna PWN, wyd. 24, Warszawa 1994, s. 848 ; wyd. 29, Warszawa 1999, s. 852; wyd. 32, Warszawa 2005, s. 888; wyd. 33, Warszawa 2006, s. 888; wyd. 34, Warszawa 2007, s. 1000; wyd. 35, Warszawa 2010, s. 1000; wyd. 36, Warszawa 2011, s. 1000; wyd. 38, Warszawa 2015, s. 1000; wyd. 39, Warszawa 2017, s. 1000.

9. Święta Lipka, w: Encyklopedia Powszechna, t. 7, Kraków 2002, s. 413 (zdj. s. 414).

10. Święta Lipka, w: Encyklopedia Powszechna PWN, t. 4, cop. Warszawa 1976, s. 392; wyd. 2, t. 4, Warszawa 1983, s. 421.

11. Święta Lipka, w: Encyklopedia Powszechna Wydawnictwa Gutenberga, t. 17, rep. Kraków 1995, s. 68.

12. Święta Lipka, w: Encyklopedia PWN w trzech tomach, t. 3, Warszawa 1999, s. 527; wyd. 2, Warszawa 2006, s. 414.

13. Święta Lipka, w: Encyklopedia wiedzy o jezuitach na ziemiach Polski i Litwy 1564-1995, wyd. 2, oprac. Ludwik Grzebień, Kraków 2004, s. 679-680.

14. Święta Lipka, w: Mała Encyklopedia Powszechna PWN, Warszawa 1974, s. 806.

15. Święta Lipka, w: Nowa encyklopedia powszechna PWN, t. 6, Warszawa 1996, s. 269; wyd. 2, t. 8, Warszawa 2004, s. 144.

16. Święta Lipka, w: Nowy Leksykon PWN, Warszawa 1998, s. 1737.

17. Święta Lipka, w: Popularna Encyklopedia Powszechna, t. 17, Kraków 1997, s. 341; t. 19, Kraków 1998, s. 40; t. 21, Kraków 2002, s. 205.

18. Święta Lipka, w: Stownik geograficzny Królestwa Polskiego i innych krajów stowiańskich, t. 11, red. B. Chlebowski, W. Walewski, Warszawa 1890, s. 690.

19. Święta Lipka, w: Wielka Encyklopedia Jana Pawła II, t. 30, oprac. G. Polak, Warszawa, s. 45.

20. Święta Lipka, w: Wielka Encyklopedia Powszechna PWN, t. 11, wyd. 1, Warszawa 1968, s. 346.

21. Święta Lipka, w: Wielka Encyklopedia PWN, t. 27, Warszawa 2005, s. 81-82. 


\section{Panorama dziejów kościoła i parafii w Świętej Lipce}

22. Achremczyk Stanisław, Święta Lipka miejscem spotkań politycznych w XVIII wieku, „Rocznik Olsztyński”, 17 (1997) s. 159-167.

23. Achremczyk Stanisław, Znaczenie Świętej Lipki w Rzeczpospolitej szlacheckiej, w: Święta Lipka: perła na pograniczu ziem, kultur i wyznań, red. A. Jacyniak, Warszawa 2008, s. 98-117.

24. Balter Lucjan, Święta Lipka na tle wiodacych sanktuariów na Warmii i Mazurach $i w$ skali ogólnopolskiej, w: Święta Lipka: perła na pograniczu ziem, kultur i wyznań, red. A. Jacyniak, Warszawa 2008, s. 17-29.

25. Bober Andrzej, Święta Lipka po dwóch latach, „Nasze Wiadomości z Prowincji Wielkopolsko-Mazowieckiej", (1949) nr 4, s. 4-7.

26. Borzyszkowski Marian, Święta Lipka w latach 1920-1940, „Studia Warmińskie", 32 (1995) s. 103-116.

27. Brillowski Wojciech, Analiza funkcjonalna założenia obronnego w Bezławkach, w: Bezławki - ocalić od zapomnienia. Wyniki prac interdyscyplinarnych prowadzonych w latach 2008-2011, red. A. Koperkiewicz, Gdańsk 2013, s. 119-136.

28. Bruski Ireneusz Stanisław, Sanktuarium świętolipskie, „Warmińskie Wiadomości Diecezjalne", 48 (1993) nr 6, 161-173.

29. Chojnowski Zbigniew, Święta Lipka w poezji i legendzie, w: Święta Lipka: perła na pograniczu ziem, kultur $i$ wyznań, red. A. Jacyniak, Warszawa 2008, s. 118-130.

30. Czapliński Konrad Kazimierz, Sanktuaria w Polsce, Katowice 2001, s. 110111.

31. Danieluk Robert, Święta Lipka w dokumentach Rzymskiego Archiwum Towarzystwa Jezusowego, w: Święta Lipka: perła na pograniczu ziem, kultur $i$ wyznań, red. A. Jacyniak, Warszawa 2008, s. 73-87.

32. Gać Jan, Święta Lipka, „Posłaniec Serca Jezusowego”, (2015) nr 4, s. 42-45.

33. Gruszka-Zych Barbara, Zaczęło się od lipy, „Gość Niedzielny”, 82 (2005) nr 30 (wkł. „Posłaniec Warmiński”).

34. Kaczorowski Andrzej, Miejsca Święte w Polsce, Poznań 2008, s. 146-149.

35. Klimek Robert, Od pogańskiego miejsca kultu do chrześcijańskiego sanktuarium - Święta Lipka i Gietrzwałd na tle krajobrazu sakralnego Warmii, „Komunikaty Mazursko-Warmińskie”, (2016) nr 3, s. 525-537.

36. Kolberg Augustyn, Geschichte der Heiligelinde, ,Zeitschrift für die Geschichte und Altertumskunde Ermlands", (1866) Bd 3, s. 28-138; 435-520.

37. Koperkiewicz Arkadiusz, Zamek $w$ Bezławkach $w$ świetle badań archeologicznych, w: Bezławki - ocalić od zapomnienia. Wyniki prac interdyscyplinarnych prowadzonych w latach 2008-2011, red. A. Koperkiewicz, Gdańsk 2013, s. 44-76.

38. Korowaj Tadeusz, Cmentarze na terenie świętolipskiej parafii, „U stóp Świętolipskiej Matki”, (2015) nr 3, s. 15-18. [Historia cmentarzy w Pieckowie, Pilcu, Pudwągach, Siemkach, Świętej Lipce i Wangutach]

39. Korowaj Tadeusz, Historia wsi Pieckowo, „U stóp Świętolipskiej Matki”, (2016) nr 5, s. 11-13. 
40. Korowaj Tadeusz, Historia wsi Pudwagi, „U stóp Świętolipskiej Matki”, (2017) $\mathrm{nr}$ 8, s. 17-19.

41. Korowaj Tadeusz, Historia wsi Wanguty, „U stóp Świętolipskiej Matki”, (2017) $\mathrm{nr}$ 7, s. 16-19.

42. Korowaj Tadeusz, Ramty - wieś w polowie drogi między Święta Lipka i Reszlem, „U stóp Świętolipskiej Matki”, (2015) nr 2, s. 7-9.

43. Korowaj Tadeusz, Święta Lipka w czasie II wojny światowej $i$ w okresie bezpośrednio powojennym, w: Święta Lipka: perła na pograniczu ziem, kultur $i$ wyznań, red. A. Jacyniak, Warszawa 2008, s. 201-224.

44. Korowaj Tadeusz, Z historii Bezławeckiego Dworu, „U stóp Świętolipskiej Matki”, (2018) nr 10, s. 8-17.

45. Korowaj Tadeusz, Z historii Lembruka, „U stóp Świętolipskiej Matki”, (2017) nr 9, s. 16-19.

46. Korowaj Tadeusz, Z liczacej 680 lat historii Klewna, „U stóp Świętolipskiej Matki”, (2016) nr 6, s. 16-19.

47. Kozłowski Krzysztof, Widziałem, jak wozili ich, „U stóp Świętolipskiej Matki”, (2016) nr 6, s. 2-5; „Gość Niedzielny”, 93 (2018) nr 23 (wkł. „Posłaniec Warmiński”), s. IV-V. [Ewakuacja pensjonariuszy domu spokojnej starości w Kętrzynie do Świętej Lipki w 1945 roku]

48. Kwiatkowski Krzysztof, Bezławki - kilka uzupetnień źródłowych dotyczacych późnośredniowiecznego zespotu osadniczego na obrzeżach kraju pruskiego, „Komunikaty Mazursko-Warmińskie”, (2016) nr 1, s. 31-54.

49. Kwiatkowski Krzysztof, (Wild)haus w Bezławkach (Bayselauken, Bäslack) uwagi na temat budownictwa warownego zakonu niemieckiego w późnośredniowiecznych Prusach, „Zapiski Historyczne”, 81 (2016) z. 2, s. 7-44.

50. Kwiatkowski Krzysztof, Zamek w Bezławkach rzekoma baza militarna zakonu niemieckiego podczas letniej wyprawy litewskiej 1402 r., „Komunikaty Mazursko-Warmińskie", (2016) nr 2, s. 203-211.

51. Legendy o Świętej Lipce, „Nasza Arka”, (2018) nr 5, s. 3.

52. Marko Elżbieta, Czy takie mogty być poczatki Świętej Lipki?, „U stóp Świętolipskiej Matki", (2014/2015) nr 1, s. 10-11.

53. Milewski Zygmunt, Święta Lipka, „Sodalis Marianus”, (1960) z. 2, s. 10-12.

54. Nowakiewicz Tomasz, Grodzisko w Bezławkach jako element średniowiecznej akcji osadniczej w Prusach krzyżackich, w: Bezławki - ocalić od zapomnienia. Wyniki prac interdyscyplinarnych prowadzonych $w$ latach 20082011 , red. A. Koperkiewicz, Gdańsk 2013, s. 235-249.

55. Obłąk Jan, Święta Lipka, Olsztyn 1975, ss. 46; wyd. 2, Olsztyn 1982, ss. 47.

56. Parda Szymon Jan, Świętolipskie jarmarki odpustowe w XIX w., „U stóp Świętolipskiej Matki”, (2015) nr 2, s. 2-5.

57. Paszenda Jerzy, Budowle jezuickie w Polsce, t. 2, Kraków 2000, s. 369-392, 393-407. [Dzieje i architektura Świętej Lipki]

58. Paszenda Jerzy, Dzieje Świętej Lipki, „Biuletyn Historii Sztuki”, 39 (1977) nr 3, s. 278-286.

59. Paszenda Jerzy, Sanktuarium świętolipskie, „Przegląd Powszechny”, (1987) nr 2, s. 220-230.

60. Paszenda Jerzy, Święta Lipka, Olsztyn 1996, ss. 128. 
61. Paszenda Jerzy, Święta Lipka. Monografia, Kraków 2008, ss. 375.

62. Pohls J., Heiligelinde in der Legende, „Illustrierter Hauskalender”, (1929) s. 54-60.

63. Poklewski Józef, Święta Lipka, Warszawa-Poznań-Toruń 1986, ss. 130.

64. Połubiński Robert, Błogosławieni, którzy w Panu umieraja, „U stóp Świętolipskiej Matki”, (2017) nr 7, s. 14-15. [Dzieje cmentarza w Lembruku (niem. Langenbrück)]

65. Połubiński Robert, Zarys historii Pilca, uroczej wsi nad jeziorem Dejnowa, „U stóp Świętolipskiej Matki”, (2014/2015) nr 1, s. 11-12.

66. Produkcja papieru w Pilcu-Niewodniku, „U stóp Świętolipskiej Matki”, (2017) nr 8, s. 16.

67. Reuther Hans, Heiligelinde. Ein unvergessliches ostpreussisches Marienheiligtum, ,Erdkreis”, (1951) s. 236-237.

68. Succincta enodatio scripti, quod nuperrime sub titulo Informatio historiojuridica de fundo ac templo beat. Virginis Mariae Ad Sacram Tiliam sito, vulgo Lindensi... prodiit, [b. aut. i m. wyd.] 1726.

69. Szczepański Seweryn, Bezławki i okolice w kontekście osadniczym plemiennej Barcji oraz kętrzyńskiego okręgu prokuratorskiego w średniowieczu, w: Bezławki - ocalić od zapomnienia. Wyniki prac interdyscyplinarnych prowadzonych w latach 2008-2011, red. A. Koperkiewicz, Gdańsk 2013, s. 14-38.

\section{Wartość artystyczna kościoła, krużganków i kaplic}

70. Babicka Maria, Krużganki w barokowych sanktuariach pielgrzymkowych na Warmii, „Biuletyn Historii Sztuki”, 28 (1966) nr 2, s. 257-260.

71. Bazylika stynna dziejami i artyzmem, „Nasza Arka”, (2018) nr 5, s. 14-15.

72. Bogdanowski Janusz, Święta Lipka, „Aura”, (1998) nr 4, s. 30-31.

73. Bosko Janina, Świętolipska perła baroku, „Posłaniec Warmiński”, (2009) nr 13 , s. 41.

74. Bötticher Adolf, Die Bau- und Kunstdenkmäler der Provinz Ostpreussen, Königsberg 1892-1899, ss. 122.

75. Buszko Eliza, Problemy konserwatorskie sanktuarium $w$ Świętej Lipce, w: Święta Lipka: perła na pograniczu ziem, kultur i wyznań, red. A. Jacyniak, Warszawa 2008, s. 176-198.

76. Chojnowski Zbigniew, Barok na Warmii, „Komunikaty Mazursko-Warmińskie", (1994) nr 1, s. 97-99.

77. Czapski Michał, Zabezpieczenie krużganków w Świętej Lipce, „Inżynieria i Budownictwo", 16 (1959) nr 1, s. 1-6.

78. Hochleitner Janusz, Kapliczki taczace Reszel ze Święta Lipka, „Przydrożne Pomniki Przeszłości”, (1991) z. 12, s. 26-31.

79. Hochleitner Janusz, Przydrożne pomniki kultu religijnego Świętej Lipki i okolic, „Studia Angerburgica”, 2 (2006) s. 78-91.

80. Jelińska Elżbieta, Ikonografia Świętej Lipki w sztuce, „Rocznik Olsztyński”, 17 (1997) s. 109-124.

81. Jelińska Elżbieta, Konserwacja zabytków ruchomych na terenie województwa olsztyńskiego w latach 1974-1987, „Olsztyński Biuletyn Konserwatorski”, (1988). [Prace konserwatorskie w latach 1982-1985] 
82. Kępkowicz Agnieszka, Sanktuarium pielgrzymkowe w Świętej Lipce a krajobraz kulturowy Warmii i Mazur, w: Swięta Lipka: perła na pograniczu ziem, kultur $i$ wyznań, red. A. Jacyniak, Warszawa 2008, s. 167-172.

83. Korowaj Tadeusz, Dziedzictwo kulturowe powiatu kętrzyńskiego. Zabytkowe obiekty sakralne, Kętrzyn 2017, s. 97-100.

84. Święta Lipka/Heiligelinde, w: Kościoły i kaplice archidiecezji warmińskiej, t. 2, red. B. Magdziarza, Olsztyn 1999, s. 12-13, 80-85.

85. Kuprjaniuk Stanisław, Mała architektura sakralna na Warmii do 1945 roku ze szczególnym uwzględnieniem kapliczek, Olsztyn 2016, s. 24, 95, 295-297, 309.

86. Marko Elżbieta, Różańcowa droga, „U stóp Świętolipskiej Matki”, (2015) nr 3, s. 12. [Historia kaplic różańcowych przy drodze z Reszla do Świętej Lipki]

87. Miłobędzki Adam, Dzieje sztuki polskiej, t. 4: Sztuka polska XVII wieku, cz. 1: Architektura polska XVII wieku, Warszawa 1980, s. 421-423.

88. Paszenda Jerzy, Architektura Świętej Lipki, „Kwartalnik Architektury i Urbanistyki”, 23 (1978) z. 1/2, s. 57-69.

89. Paszenda Jerzy, Architektura zespołu kościelnego w Świętej Lipce na tle polskiego baroku, „Komunikaty Mazursko-Warmińskie”, 37 (1993) nr 4, s. 511518.

90. Paszenda Jerzy, Stachurski Andrzej, Święta Lipka. Bazylika mniejsza, Olsztyn 2010, ss. 95.

91. Poklewski Józef, Święta Lipka - polska fundacja barokowa na terenie Prus Książęcych, Warszawa-Poznań 1974, ss. 184.

92. Reifferscheid Gerhard, Heiligelinde. Schönste Barockkirche Ostpreussens, Münster 1982, ss. 83.

93. Rzempołuch Andrzej, Prace rzeźbiarza Krzysztofa Perwangera dla kościoła w Świętej Lipce 1744-1748, „Biuletyn Historii Sztuki”, 55 (1993) nr 1, s. 4961.

94. Sanktuarium Świętolipskiej Madonny, „Nasza Arka”, (2018) nr 5, s. 16-17.

95. Smoliński Mariusz, Święta Lipka, „Spotkania z Zabytkami”, (2001) nr 8, s. 18-20.

96. Stoga Andrzej, Iluzjonistyczne malowidła Macieja Mejera w Świętej Lipce i ich znaczenie $w$ sztuce polskiej XVIII w., ,Komunikaty Mazursko-Warmińskie", (1994) nr 4, s. 519-527.

97. Stoga Andrzej, Malarstwo ścienne na Warmii i jego oddziatywanie, w: Sztuka 1 pot. XVIII wieku, red. H. Lisińska, Warszawa 1981, s. 249-264.

98. Stoga Andrzej, Quadratura w malarstwie polskim XVIII w. Malowidta na sklepieniach, „Biuletyn Historii Sztuki”, 42 (1980) nr 3/4, s. 365-376.

99. Vetulani Cecylia, Konserwacja zabytków $w$ województwie olsztyńskim (1 I 1953 - 30 XI 1955), „Komunikaty Mazursko-Warmińskie”, (1958) nr 3, s. 288-301. [Renowacja krużganków w latach 1950-1959]

100. Ulbrich Anton, Kunstgeschichte Ostpreussens von der Ordenszeit bis zur Gegenwart, Königsberg 1932, ss. 272.

101. Ulbrich Anton, Die Wallfahrtskirche in Heiligelinde. Ein Beitrag zur Kunstgeschichte des XVII. und XVIII. Jahrhunderts in Ostpreussen, Strassburg 1901, ss. 94. 
102. Wagner Arkadiusz, Rzeźbiarska grupa Zwiastowania ze Świętej Lipki: z badań nad działalnościa warsztatu Krzysztofa Perwangera, „Prace Wydziału Filologiczno-Filozoficznego", 37 (2005) z. 3, s. 204-213.

103. Wanat-Zakrzewska Maria, Konserwacja rzeźby kamiennej barokowego kościoła w Świętej Lipce w latach 1982-1987, „Rocznik Olsztyński”, 17 (1997) s. $125-141$.

\section{Barokowe organy Jana Jozuego Mosengela}

104. Buchholz Franz, Der Bau der Heiligelinder Orgel, „Zeitschrift für die Geschichte und Altertumskunde Ermlands", 27 (1942) s. 437-444.

105. Dzieło organmistrza z Królewca, „Nasza Arka”, (2018) nr 5, s. 20-21.

106. Gołos Jerzy, Polskie organy i muzyka organowa, Warszawa 1972, s. 280, 288, 362. [Jan Mosengel z Królewca, Max Terlecki z Elbląga, organy świętolipskie]

107. Jacyniak Aleksander, Brat Waldemar Strzyżewski, w: Święta Lipka: perła na pograniczu ziem, kultur i wyznań, pod red. Aleksandra Jacyniaka, Warszawa 2008, s. 366-369. [Kazanie wygłoszone w czasie pogrzebu br. Waldemara Strzyżewskiego, jezuity i organisty świętolipskiego, 1 lutego 2006 roku]

108. Katalog zabytków sztuki w Polsce: seria nowa, t. 2: woj. elbląskie, z. 1: Braniewo, Frombork, Orneta i okolice, pod red. Mariana Arszyńskiego i Mariana Kutznera, Warszawa 1980, s. XXXIV, XXXV.

109. Krollmann Christian, Mosengel Johann Josua (1663-1731), w: Altpreussische Biographie, t. 2, Magdeburg 1967.

110. Renkewitz Werner, Janca Jan, Geschichte der Orgelbaukunst in Ost - und Westpreussen von 1333 bis 1944, Bd 2,1: Mosengel, Caspari, Casparini, Köln 2008, ss. 491.

111. Sianko Józef, Barokowe organy z XVIII w. na terenie diecezji warmińskiej, „Studia Warmińskie”, 8 (1971) s. 49-83.

112. Sianko Józef, Organy w kościele ojców jezuitów w Świętej Lipce, „Studia Warmińskie", 8 (1971) s. 62-68.

113. Smulikowska Ewa, Prospekty organowe $w$ dawnej Polsce, Wrocław 1989, s. 23, 125, 128, 157-159, 215, 237, 238, 264, 265, 276.

114. Sulima Rafał, Organy świętolipskie, w: Święta Lipka: perła na pograniczu ziem, kultur $i$ wyznań, red. A. Jacyniak, Warszawa 2008, s. 131-146.

\section{Jezuici jako gospodarze kościoła świętolipskiego}

115. Bartlewicz Jan, Brat Franciszek Seroczyński SJ, w: Święta Lipka: perła na pograniczu ziem, kultur i wyznań, red. A. Jacyniaka, Warszawa 2008, s. 366369. [Kazanie wygłoszone na pogrzebie br. Franciszka Seroczyńskiego, jezuity, kwiecień 2004 roku]

116. Bulanda Edward, Dtugoletni kustosz bazyliki świętolipskiej Br. Aleksy Lizata-odwołany przez Pana. „Komunikaty Prowincji Wielkopolsko-Mazowieckiej" (1973), nr 1, s. 7-10.

117. Daleczko Władysław (1910-1991), w: Mały stownik jezuitów w Polsce, red.

F. Paluszkiewicz, Warszawa 1995, s. 52.

118. Engell (Engel) Michat (XVII-XVIII w.), w: Stownik Biograficzny Warmii, 
Mazur i Powiśla od połowy XV wieku do 1945 roku, red. T. Oracki, Warszawa 1963 , s. 71.

119. Darowski Roman, Gorgoniusz Ageison SJ (1604-1665), profesor w Akademii Wileńskiej, „Prawo Kanoniczne”, 22 (1979) nr 3-4, s. 263-275.

120. Dzwonkowski Roman (oprac.), Zabek Antoni (1899-1989), w: Leksykon duchowieństwa polskiego represjonowanego w ZSRS 1939-1988, Lublin 2003, s. 667-670.

121. Grzebień Ludwik (red.), Antoniewicz Józef (1880-1950), w: Stownik Polskich Teologów Katolickich, t. 5, Warszawa 1983, s. 51-52, bibliogr.

122. Grzebień Ludwik, Aucepius Teodor (1691-1773), w: Stownik Polskich Teologów Katolickich, t. 1, red. H.E. Wyczawski, Warszawa 1981, s. 77-78, bibliogr.

123. Grzebień Ludwik, Klage (Clagius) Tomasz (ok. 1598-1664), w: Stownik Polskich Teologów Katolickich, t. 2, ed. H.E. Wyczawski, Warszawa 1982, s. 281-283, bibliogr.

124. Grzebień Ludwik, Nahzer Michat (1687-1758), w: Stownik Polskich Teologów Katolickich, t. 3, ed. H.E. Wyczawski, Warszawa 1982, s. 192, bibliogr.

125. Grzebień Ludwik, Rochel (Rochell) Jan (1664-1708), w: Stownik Polskich Teologów Katolickich, t. 3, ed. H.E. Wyczawski, Warszawa 1982, s. 500, bibliogr.

126. Grzebień Ludwik, Schill Grzegorz (1625-1700), w: Stownik Polskich Teologów Katolickich, t. 4, ed. H.E. Wyczawski, Warszawa 1983, s. 26-27, bibliogr.

127. Grzebień Ludwik, Stempel Maciej (ok. 1621-1697), w: Słownik Polskich Teologów Katolickich, t. 4, ed. H.E. Wyczawski, Warszawa 1983, s. 208, bibliogr.

128. Harwardt B., Pater Heribert Schulz, „Mitteilungen aus deutsche Provinzen der Gesellschaft Jesu", 16 (1946-1948) s. 59-61.

129. Jacyniak Aleksander, Brat Bronisław Bitrowicz SJ: 36 lat postugiwat w Świętej Lipce, w: Święta Lipka: perła na pograniczu ziem, kultur i wyznań, red. A. Jacyniak, Warszawa 2008, s. 359-361.

130. Jacyniak Aleksander (red.), Brat Waldemar Strzyżewski, w: Święta Lipka: perta na pograniczu ziem, kultur i wyznań, Warszawa 2008, s. 366-369. [Kazanie wygłoszone w czasie pogrzebu br. Waldemara Strzyżewskiego, jezuity i organisty świętolipskiego, 1 lutego 2006 roku]

131. Jacyniak Aleksander (red.), Brat Zygmunt Geppert SJ: 30 lat postugiwat w Świętej Lipce, w: Święta Lipka: perła na pograniczu ziem, kultur $i$ wyznań, Warszawa 2008, s. 362-365. [Kazanie wygłoszone w czasie pogrzebu br. Zygmunta Gepperta, Święta Lipka, 27 stycznia 2005 roku]

132. Jacyniak Aleksander, Ojciec Heribert Schulz jezuita, „Miejsca Święte”, (2008) nr 5, s. 42.

133. Jodelis Wincenty, O ojcu Antonim Zabku w Świętej Lipce wspomnienie sprzed 26 lat, „U stóp Świętolipskiej Matki”, (2017) nr 8, s. 14-15.

134. Jubileusz w Gdańsku, „Komunikaty Prowincji Wielkopolsko-Mazowieckiej”, (2007) nr 10, s. 11. [Złoty jubileusz zakonny o. Janusza Motylińskiego] 135. Lenz Edmund, Kazanie na pogrzebie O. Antoniego Zabka, „Komunikaty 
Prowincji Wielkopolsko-Mazowieckiej", (1989) nr 5, s. 14-17.

136. Lizała Aleksy (1907-1973), w: Mały słownik jezuitów w Polsce, red. F. Paluszkiewicz, Warszawa 1995, s. 129.

137. Lühr Georg, Die Jesuiten von Rösel und Heiligelinde, „Zeitschrift für die Geschichte und Altertumskunde Ermlands", 20 (1919) nr 20, s. 753-800.

138. Musialik Wanda, Cieszyński Klaus Peter, w: Leksykon duchowieństwa represjonowanego w PRL w latach 1945-1989, t. 3, red. J. Myszor, Warszawa 2006, s. 28-30.

139. Natoński Bronisław, Klage Tomasz (ok. 1598-1664), w: Polski Słownik Biograficzny, t. 12, Wrocław 1990, s. 537-538.

140. O. Antoni Ząbek, „Komunikaty Prowincji Wielkopolsko-Mazowieckiej”, (1989 $\mathrm{nr}$ 4, s. 26-28.

141. O. Józef Mach, „Komunikaty Prowincji Wielkopolsko-Mazowieckiej”, (1991) nr 7/8, s. 8-9.

142. Paszenda Jerzy, Brat Aleksy Lizata SJ, „Komunikaty Prowincji Wielkopolsko-Mazowieckiej", (2003) nr 1, s. 17-19.

143. Paszenda Jerzy, Brat Aleksy Lizała: 21 lat postugiwat w Świętej Lipce, w: Święta Lipka: perła na pograniczu ziem, kultur i wyznań, red. A. Jacyniak Warszawa 2008, s. 355-358.

144. Paszenda Jerzy, Żywot ojca Barttomieja Möllera SJ, „Komunikaty Mazursko-Warmińskie", (2002) nr 2, s. 205-211.

145. Paziewski Michał, Sroka Bronistaw (1936-), w: Leksykon duchowieństwa represjonowanego w PRL w latach 1945-1989, t. 3, red. J. Myszor, Warszawa 2006, s. 224-226.

146. Piskorek Julian, Wspomnienie o O. Janie Pastuszce, „Komunikaty Prowincji Wielkopolsko-Mazowieckiej”, (1986) nr 1/2, s. 17-25.

147. Poschmann Adolf, Das Jesuitenkolleg in Rössel, Braunsberg 1932, ss. 155.

148. Szymański Stanisław, Brat Jan Lukawski SJ: 14 lat postugiwat w Świętej Lipce, w: Święta Lipka: perła na pograniczu ziem, kultur i wyznań, red. A. Jacyniak, Warszawa 2008, s. 351-354.

149. Śp. O. Mieczysław Woloszyn SJ (1933-2017), „Warmińskie Wiadomości Archidiecezjalne", 66 (2017) nr 145, s. 93.

150. Święta Lipka, w: Encyklopedia wiedzy o jezuitach na ziemiach Polski i Litwy 1564-1995, red. L. Grzebień, wyd. 2, Kraków 2004, s. 679-680.

151. Władystaw Daleczko, „Komunikaty Prowincji Wielkopolsko-Mazowieckiej", (1991) nr 6, s. 8.

152. Wspomnienie o ojcu Mieczystawie Woloszynie w rok po jego śmierci, „U stóp Świętolipskiej Matki”, (2018) nr 10, s. 4-5.

153. Załęski Stanisław, Jezuici w Polsce, t. 4: Dzieje 153 kolegiów i domów jezuitów w Polsce, Kraków 1905, s. 1347-1360.

\section{Obraz Matki Bożej Świętolipskiej}

154. Barącz Sadok, Cudowne obrazy Matki Najświętszej w Polsce, Lwów 1891, s. $145-146$. 
155. Czapliński Konrad Kazimierz, Koronowane Madonny polskie, ChorzówKatowice 2007, s. 85.

156. Fridrich Alojzy, Historye cudownych obrazów Najświętszej Maryi Panny w Polsce, t. 1, Kraków 1903, s. 385-390.

157. Jacyniak Aleksander, Wymowa obrazu Matki Bożej Świętolipskiej, w: Święta Lipka: perła na pograniczu ziem, kultur $i$ wyznań, red. A. Jacyniak, Warszawa 2008, s. 54-66.

158. [Nowakowski Edward] Ks. Wacław z Sulgostowa, O cudownych obrazach w Polsce Przenajświętszej Matki Bożej. Wiadomości historyczne, bibliograficzne i ikonograficzne, Kraków 1902, s. 641-645.

159. Wielka dobroć Maryi, „Nasza Arka”, (2018) nr 5, s. 10-11.

\section{Cuda i laski za wstawiennictwem Matki Bożej Świętolipskiej}

160. Bochenek Małgorzata, Częstochowa Pólnocy, „Nasz Dziennik”, (2018) nr 143, s. 24.

161. Ciaritius Michael Fridericus, B. V. M. Lindensis. Vetustissimum et religiossimum in Prussia Sacellum Beatissimae Virginis Mariae sacrum, prodigiis divinis clarissimum, Brunsbergae 1626.

162. Clagius Thomas [Klage Tomasz], Linda Mariana sive de B. Virgine Lindensi libri $V$, Coloniae 1659.

163. Gnaden-Brunn Aus dem Marianischen Paradeiss der zart grünenden Heiligen Linde entsprossen; Welcher sich durch nahe bey vier hundert Jahr In Strohm reichen Wunderbächen huffig ergossen; Jetzt durch Historische Verfassung Nebstanmüthigen Andachtigen Wahlfahrteren vorgestellet, Braunsberg 1773.

164. Grundlicher Bericht von Catholischer verehrung unserer lieben Frawen und Gottes Gebährerin Maria. Zu dero selen Ehre an dem H. Ort Linde genant grösserer vermehrung: Allen Lutherischen aber sonderlich denen, sodem H. Ort Linde benachbahret sein, zu heylsamen unterricht. Auss Unterschiedlichen bewehrten Authoren und streit schrifften, Auff Anhaltem einer hohen Persohnen zusammen getragen, Braunsberg 1667.

165. Historia Lindensis Das ist Kurzer Inhalt von der Wunderthatigen Capell unser Engelreiner Jungfrauen Und Mutter Gottes Maria zur H. Lind. Beschrieben durch R.P. Thomam Clagium SI, Anno 1667 von Etlichen Mariae Liebhaberen ins Teutsch versetzt zu Braunsberg.

166. Jacyniak Aleksander, Chcę stużyć Matce Bożej Świętolipskiej (rozmowa z Franciszkiem Mrozem), „Nasza Arka”, (2018) nr 5, s. 12-13.

167. Jagla Jowita, Obraz chorób $w$ malowidłach $z$ warmińskich sanktuariów w Świętej Lipce i Chwalęcinie - refleksje porównawcze, „Medycyna Nowożytna", 18 (2012) z. 1/2, s. 131-165.

168. Kozłowski Krzysztof, Bogu o miłość chodzi, „Gość Niedzielny”, 95 (2018) nr 32 (wkł. „Posłaniec Warmiński”), s. VI-VII.

169. Krasowska Helena, Kolejne świadectwo uzdrowienia w świętolipskim sanktuarium, „U stóp Świętolipskiej Matki”, (2017) nr 9, s. 2-3.

170. Krótka wiadomość o początkach i pomnożeniu nabożeństwa i cudów na stynacym wielkimi łaskami Maryi Panny miejscu Świętej Lipki z różnych history- 
ków wyjęta. Za dozwoleniem zwierzchności kościelnej; dawniej w niemieckim języku wydana, teraz na polski język z tymże dozwoleniem przetożona, $\operatorname{Br}[\mathrm{a}]$ unsberg 1770.

171. Opisanie miejsca Święta Lipa, czyli Święta Lipka nazwanego, z przytaczeniem świętobliwych uwag, duchownych ćwiczeń, i pobudek, oraz pieśni i modlitw. Dla wygody pobożnie toż miejsce odwiedzaiacych osób z Niemieckiey ksiażki dawniey wydrukowaney i Roku 1773 znowu przedrukowaney, na Polski zaś język Roku 1770 przettómaczoney, a teraz znowu po polsku z niektóremi ważnemi odmianami i przydatkami wydane. Za Pozwoleniem Zwierzchności, Warszawa 1805.

172. Paszenda Jerzy, Cuda i łaski w Świętej Lipce, w: Święta Lipka: perła na pograniczu ziem, kultur i wyznań, pod red. Aleksandra Jacyniaka, Warszawa 2008, s. 167-175.

173. Paszenda Jerzy, Święta Lipka: czytanki majowe, Olsztyn 1996, ss. ?????.

174. Szymański Stanisław, Matka Boska Świętolipska: czytanki majowe, Kraków 1994, ss. 171.

175. Szymański Stanisław, Matka Boska Świętolipska: rozważania majowe, red. A. Jacyniak, Olsztyn 2018, ss. 106.

176. Wołodkowicz Kazimierz, Ode votiva Reginae Coelorum Lindensi In Prussia Varmiensis Episcopatus cunfedera Polonos Inter Suecos Gedani necterentur a Partu Virginis MDCLV..., Cracoviae 1661.

\section{Ruch pielgrzymkowy i turystyczny}

177. Bielawny Krzysztof, Dzieje katolików polskich w diecezji warmińskiej w latach 1918-1945 w refleksji historyczno-teologicznej, Olsztyn 2007, s. 136-146.

178. Bielawny Krzysztof, Kościół katolicki i ewangelicki na przestrzeni sześciu stuleci w poludniowej części starostwa szestneńskiego. Studium historyczno-ekumeniczne, Olsztyn 2009, s. 252-255; 403-405

179. Birch-Hirschfeld Anneliese, Ermländische Heiligelindepilger um die Mitte des 17. Jahrhunderts, ,Zeitschrift für die Geschichte und Altertumskunde Ermlands", 26 (1938) s. 430-450.

180. Bruski Ireneusz, Sanktuarium Matki Jedności Chrześcijan w Świętej Lipce, Olsztyn 1993, ss. 57.

181. Bruździńska Jadwiga, ,Caritas Academica” z Łodzi na wczasach w Świętej Lipce latem 1947 r., w: Święta Lipka: perła na pograniczu ziem, kultur $i$ wyznań, red. A. Jacyniak, Warszawa 2008, s. 225-227.

182. Clagius Thomas [Klage Tomasz], Linda Mariana sive de B. Virgine Lindensi libri $V$, Coloniae 1659.

183. Czechyra Łukasz, Ona zna drogę, „Gość Niedzielny”, 95 (2018) nr 31, s. III. [Rozmowa z bp. Januszem Ostrowskim nt. uroczystości junbileuszowych 11 sierpnia 2018 roku]

184. Der Wallfahrtsort Heiligelinde in der Diözese Ermland, Braunsberg 1938, ss. 82.

185. Helik Adrian, Wakacyjny pobyt ministrantów i scholanek $w$ Świętej Lipce, „U stóp Świętolipskiej Matki”, (2015/2016) nr 4, s. 5-6.

186. Hochleitner Janusz, Modne sanktuaria. Warmińskie ośrodki pielgrzymkowe 
w XIX wieku, w: Życie prywatne Polaków w XIX wieku, t. 6: Moda i styl życia, red. J. Kita i M. Korybut-Marciniak, Łódź-Olsztyn 2017, s. 63-82.

187. Hochleitner Janusz, Nowożytne pielgrzymki w życiu społecznym Warmii, „Echa Przeszłości”, 7 (2006) s. 25-39.

188. Hochleitner Janusz, Religijność Mazurów manifestowana w Świętej Lipce (XVI-XX w.), w: Mniejszość i większość. Relacje kulturowe na pograniczach, cz. 1, red. P. Pietnoczka, Olsztyn 2016, s. 175-192.

189. Hochleitner Janusz, Religijność potrydencka na Warmii (1551-1655), Olsztyn 2000, s. 203-207.

190. Hochleitner Janusz, Warmińskie łosiery. Studium lokalnego pielgrzymowania, Olsztyn 2013, s. 86-95.

191. Jasiński Janusz, Pielgrzymki do Świętej Lipki od schytku XVIII do początku XX wieku, „Zapiski Historyczne poświęcone historii Pomorza i krajów bałtyckich", 56 (1991) z. 4, s. 71-93.

192. Kaczorowski Robert, Pieśni do Matki Bożej ze Świętej Lipki w świetle rękopisu 70 z Muzeum Warmii i Mazur w Olsztynie, „Rocznik Gdański”, 62 (2002) z. $1 / 2$, s. 167-184.

193. Kaczorowski Robert, Święta Lipka: studium o tradycji pielgrzymkowej i kulturze muzycznej, Gdańsk 2002, ss. 220.

194. Klafki Leo, Wallfahrtskirche Heiligelinde (Święta Lipka), [1980].

195. Kowalewska Magdalena, Kajakiem do Świętej Lipki. Tutaj studenci nieśli ks. Wojtyte na rękach, „Niedziela”, 42 (2011) s. 14-15.

196. Kozłowski Krzysztof, Pielgrzymi z bliska i daleka, „Gość Niedzielny”, 91 (2014) nr 14 (wkł. „Posłaniec Warmiński”).

197. Lieder Franciszek, Warmia moich młodych lat, Olsztyn 1986, s. 111-112. [Opis XIX-wiecznego odpustu Nawiedzenia NMP w Świętej Lipce]

198. lucy, Na Maryjnym szlaku, „Gość Niedzielny”, 95 (2018) nr 31, s. I. [Pielgrzymka parafialna z Mrągowa do Świętej Lipki]

199. Matczak Bartłomiej, I Archidiecezjalna Pielgrzymka Stużby Liturgicznej do Świętej Lipki, „U stóp Świętolipskiej Matki”, (2016) nr 6, s. 6-7.

200. Matczak Bartłomiej, I Pielgrzymka Stużby Liturgicznej, Święta Lipka 2016, „Warmińskie Wiadomości Archidiecezjalne”, 71 (2016) nr 142, s. 80.

201. Mitura A., Święta Lipka (Linda Mariana). Ośrodek polskiego życia religijnego na Mazurach, Warszawa 1946.

202. Mróz Franciszek, Pielgrzymowanie do sanktuarium Matki Bożej Świętolipskiej w latach 1996-2007, w: Święta Lipka: perła na pograniczu ziem, kultur i wyznań, red. A. Jacyniak, Warszawa 2008, s. 324-334.

203. Nowak Władysław, Promieniowanie sanktuarium Matki Bożej Świętolipskiej na Prusy, w: Przeszłość natchnieniem teraźniejszości. Sympozjum historyczne i świętowojciechowe, Ełk, 20-22 kwietnia 1994 roku, red. K. Brzostek i in., Ełk 1996, s. 143-154.

204. Nowak Władysław, Sanktuarium Matki Jedności chrześcijan w Świętej Lipce, „Warmińskie Wiadomości Archidiecezjalne”, 48 (1993) z. 7, s. 110-112.

205. Nowak Władysław, Sanktuarium NMP w Świętej Lipce a kult maryjny wśród protestantów na Mazurach, „Przegląd Powszechny”, (1983) nr 5/6, s. 217230. 
206. Paszenda Jerzy, Jezuici w Myszyńcu, w: Dzieje parafii i kościoła pod wezwaniem Trójcy Przenajświętszej w Myszyńcu, red. M. Przytocka, Myszyniec 2009, s. 59-78. [Pielgrzymki Kurpiów do Świętej Lipki w XVII wieku]

207. Paszenda Jerzy, Pielgrzymowanie do Świętej Lipki dawniej i dziś, „Peregrinus Cracoviensis", 6 (1998) s. 137-162.

208. Pielgrzymka gwiaździsta do Świętej Lipki. Uroczyste ogłoszenie nadania tytułu bazyliki mniejszej sanktuarium maryjnemu w Świętej Lipce, „Warmińskie Wiadomości Diecezjalne”, 5/6 (1983) s. 248.

209. Przydatek Kazimierz, Ks. bp nominat Karol Wojtyła w Świętej Lipce, w: Święta Lipka: perła na pograniczu ziem, kultur $i$ wyznań, red. A. Jacyniak, Warszawa 2008, s. 232-234.

210. Przydatek Kazimierz, To było 50 lat temu. Pierwsze spotkanie z ks. Karolem Wojtyta w Świętej Lipce, „Miejsca Święte”, (2008) nr 5, s. 38-39.

211. Ropiak Sławomir, Pieśni świętolipskie, w: Święta Lipka: perła na pograniczu ziem, kultur i wyznań, red. A. Jacyniak, Warszawa 2008, s. 147-166.

212. Święta Lipka [Linda Mariana]. Ośrodek polskiego życia religijnego na Mazurach, Warszawa 1946, ss. 12; Warszawa 1980, ss. 13.

213. Wandali Mamert, Pielgrzymka kurpiowska do Świętej Lipki na Warmii katolickiej w Prusach Wschodnich, „Przegląd Powszechny”, (1987) nr 5, s. 231240.

214. Wujkowi z okazji 20-lecia pontyfikatu, 40-lecia sakry biskupiej i 40-lecia „Świętej Lipki”, „U stóp Świętolipskiej Matki”, (2018) nr 10, s. 17-19. [Wspomnienia studentów KUL o obozie wakacyjnym z ks. Karolem Wojtyłą w Świętej Lipce w 1958 roku]

215. Xps, Inaczej spojrzeć na życie: pielgrzymka bezdomnych do Świętej Lipki, „Gość Niedzielny”, 95 (2018) nr 26 (wkł. „Posłaniec Warmiński”), s. IV.

216. Zientara-Malewska Maria, Miłość prostego serca: wiersze religijne, Olsztyn 1985, s. 59-64.

217. Zientara-Malewska Maria, Warmio moja miła, Warszawa 1959, s. 142-145. Pielgrzymka olsztyńska do Świętej Lipki

\section{Szkoła muzyczna}

218. Kaczorowski Robert, Święta Lipka: studium o tradycji pielgrzymkowej i kulturze muzycznej, Gdańsk 2002, ss. 220.

219. Kopiczko Andrzej, O Feliksie Nowowiejskim w zbiorach Archiwum Archidiecezji Warmińskiej w Olsztynie, w: Kompozytor - dzieło - tradycja: prace badawcze poświęcone Feliksowi Nowowiejskiemu, red. K. Szatrawski, Barczewo 2017, s. 11-20.

220. Kochanowicz Jerzy, Stownik geograficzny jezuickich burs muzycznych (Materiały), Kraków 2002, s. 219-222.

221. Marko Elżbieta, Szkoła muzyczna w Świętej Lipce, „U stóp Świętolipskiej Matki", (2016) nr 5, s. 6-8.

222. Obłąk Jan, Szkoła muzyczna w Świętej Lipce, „Komunikaty Mazursko-Warmińskie", 69 (1960) nr 3, s. 351-371.

223. Rondomańska Zofia, Polonica w katalogu muzykaliów świętolipskich, „Komunikaty Mazursko-Warmińskie", (1998) nr 3, s. 383-394. 
224. Szatrawski Krzysztof Dariusz, Feliks Nowowiejski: kompozytor z Barczewa, „Borussia”, (2016) nr 57, s. 46-54.

225. Zadroga Danuta, Muzykalia świętolipskie przechowywane w Bibliotece Bobolanum w Warszawie, w: Święta Lipka: perła na pograniczu ziem, kultur i wyznań, red. A. Jacyniak, Warszawa 2008, s. 92-97.

\section{Uroczystości religijne}

226. Barczewski Walenty, Nowe kościoły katolickie na Mazurach, Olsztyn 1925, ss. 18. [Odpusty świętolipskie i działalność misyjna jezuitów]

227. Borzyszkowski Marian, Uroczystości maryjne w Świętej Lipce, „Warmińskie Wiadomości Diecezjalne”, 24 (1969) nr 1, s. 6-17. [Koronacja obrazu Matki Bożej Świętolipskiej]

228. Cieślak Anna, Uroczystości jubileuszowe w Świętej Lipce, „Posłaniec Warmiński” 2008, nr 19, s. 11.

229. DEM, Ratująca Matka, „Gość Niedzielny”, 90 (2013) nr 34 (wkł. „Posłaniec Warmiński").

230. Drzazga Józef, Prośba Księdza Biskupa Warmińskiego skierowana do Ojca Świętego Pawta VI o przyznanie kościołowi w Świętej Lipce tytułu Bazyliki Mniejszej, „Warmińskie Wiadomości Diecezjalne”, 33 (1978),nr 4, s. 157.

231. Drzazga Józef, Przemówienie Biskupa dr Drzazgi, ordynariusza diecezji warmińskiej, wygłoszone 11 sierpnia 1968 w Świętej Lipce, „Warmińskie Wiadomości Diecezjalne", 24 (1969) nr 1, s. 18-20.

232. Jacyniak Aleksander, [Kazanie na świętolipskim cmentarzu w uroczystość Wszystkich Świętych 1 XI 2015], „U stóp Świętolipskiej Matki”, (2015/2016) $\mathrm{nr} 4$, s. 10-14. [Historia zbrodni żołnierzy radzieckich na mieszkańcach Świętej Lipki w 1945 roku]

233. Jacyniak Aleksander, Stowo na 30-lecie kapłaństwa o proboszcza, „U stóp Świętolipskiej Matki”, (2015) nr 3, s. 5-7.

234. Jacyniak Aleksander, Stowo na rozpoczęcie postugi proboszcza parafii i kustosza sanktuarium, „U stóp Świętolipskiej Matki”, (2014/2015) s. 6-7.

235. Jacyniak Aleksander, Odpust Nawiedzenia Najświętszej Maryi Panny, „U stóp Świętolipskiej Matki”, (2017) nr 8, s. 12.

236. Jacyniak Aleksander, Uroczystości odpustowe Nawiedzenia Najświętszej Maryi Panny, „U stóp Świętolipskiej Matki”, (2015) nr 3, s. 4.

237. Jacyniak Aleksander, Uroczystości odpustowe Nawiedzenia Najświętszej Maryi Panny, „U stóp Świętolipskiej Matki”, (2016) nr 6, s. 5-6.

238. Jan Paweł II [Karol Wojtyła], Uroczyste ogłoszenie tytułu bazyliki mniejszej sanktuarium maryjnemu w Świętej Lipce, „Warmińskie Wiadomości Diecezjalne", 38 (1983) nr 5/6, s. 248-149.

239. Kętrzyński Wojciech, Szkice, wyd. 2, Olsztyn 1984, ss. XXVII, s. 115-116.

240. Kętrzyński Wojciech, Szkice Prus Wschodnich, „Przewodnik Naukowy i Literacki”, 4 (1896) s. 456-461.

241. Kopiczko Andrzej, Nawiedzenie II. Druga Peregrynacja Kopii Obrazu Jasnogórskiego $w$ diecezji warmińskiej (1986-1987), Olsztyn 2018, s. 41, 59, 74, 174. [Peregrynacja w Świętej Lipce, 30 maja 1987 roku] 
242. Kopiczko Andrzej, Władze partyjno-państwowe wobec koronacji obrazu Matki Bożej w Świętej Lipce, w: Święta Lipka: perła na pograniczu ziem, kultur $i$ wyznań, red. A. Jacyniak, Warszawa 2008, s. 245-300.

243. Kozłowski Krzysztof, Będziesz ukoronowana!, „Gość Niedzielny”, 95 (2018) nr 33 (wkł. „Posłaniec Warmiński”), s. VI-VII. [Uroczystości koronacyjne w 1968 i 2018 roku]

244. Kozłowski Krzysztof, Byli tu królowie, „Gość Niedzielny” 94 (2017), nr 33 (wkł. Posłaniec Warmiński”), s. I. [Monstrancja fatimska w Świętej Lipce]

245. Kozłowski Krzysztof, Jest Mistrzynia, „Gość Niedzielny”, 95 (2018) nr 33 (wkł. „Posłaniec Warmiński”). [Inauguracja nabożeństw fatimskich pod przewodnictwem abp. Józefa Górzyńskiego 13 maja 2018 roku]

246. Kozłowski Krzysztof, Wszystko minęło, a Ona została, ,Gość Niedzielny”, 95 (2018) nr 33 (wkł. „Posłaniec Warmiński”), s. I. [Jubileusz 50-lecia koronacji obrazu Matki Bożej Świętolipskiej, 11 sierpnia 2018]

247. Lieder Franciszek, Warmia moich młodych lat, Olsztyn 1986, s. 111-112.

248. Łękawski Krzysztof, Chyra Maciej „Łoś”, Jezuickie Dni Młodzieży: Święta Lipka, 13-21 lipca 2002, Opole 2002, ss. 21.

249. Nowak Władysław, Treści teologiczne liturgii koronacji $i$ ich wpływ na ksztalt kultu Matki Bożej Świętolipskiej, w: Święta Lipka: perła na pograniczu ziem, kultur i wyznań, red. A. Jacyniak, Warszawa 2008, s. 309-323.

250. Połubiński Robert, Nowe relikwie dla świętolipskiego sanktuarium, „U stóp Świętolipskiej Matki”, (2016) nr 5, s. 14-15. [Wprowadzenie relikwii bł. Aleksandry Marii da Costa, bł. Dominiki Lentini, bł. Anny Gattorno, bł. Anny Mogas, św. Józefiny Bakhity, bł. Piotra Ruiz de los Panos y Angel, bł. Anieli od św. Józefa, bł. Mikołaja da Gesturi i bł. Marii od Męki Pańskiej]

251. Szembek Krzysztof Andrzej Jan, bp, Roze Tejemnic Niebieskich Pasterska Praca Kwitnace ... Albo Kazania ... Krzysztofa Andrzeia Jana Na Stupowie Szembeka Biskupa Warmińskiego y Sambińskiego ... W Różnych Kościołach Dyecezyi swoich ... Miane / Od najnizszych Stug OO. S.J. u Swiętey Lipki Missyonarzow w iednym Tomie na trzy części Rozłozone, [Braniewo] 1740.

252. Szembek Krzysztof Andrzej Jan, bp, Seelen-Stärckender Rosen-Seym ... Von den Hoch-Fürstlichen Stamm-Rosen Des Durchlaüchtigsten ... H. Christophori, Andrea, Joannis Graffen in Stupow Szembek, Bischoffen zu Ermland ... / Von dero Unterthänigsten Dieneren Den PP. Soc. Jesu bey der H. Linde Zum Denckmahl ihrer dienst-verbundenen Schuldigkeit zugeschrieben, Brunsbergae 1736.

253. Szembek Krzysztof Andrzej Jan, bp, Seelen-Stärckender Rosen-Seym ... Von den Hoch-Fürstlichen Stamm-Rosen Des Durchlaüchtigsten ... H. Christophori, Andrece, Joannis Graffen in Stupow Szembek, Bischoffen zu Ermland ... IVon den Unterthänigsten Dieneren PP. Soc. Jesu bey der H. Linde zusammen getragen, Brunsbergae 1740.

254. Trochimczuk Monika, Światowe Dni Młodzieży w Świętej Lipce, „U stóp Świętolipskiej Matki", (2016) nr 6, s. 10-12.

255. Wasilewski Czesław, Młodzi w Świętej Lipce, „U stóp Świętolipskiej Matki”, (2015) nr 3, s. 13. 
256. Uroczystość Wniebowzięcia NMP, „U stóp Świętolipskiej Matki”, (2015/2016) nr 4, s. 3-4.

257. W wierze zwycięstwo, „Nasz Dziennik”, (2018) nr 186 (6240), s. 10. [Relacja z uroczystości 50-lecia koronacji obrazu Matki Bożej Świętolipskiej, 11 sierpnia 2018 roku]

258. Wyszyński Stefan, Święta Lipka - szańcem wiary - [kazanie] podczas koronacji obrazu Matki Bożej Święta Lipka, 11 sierpnia 1968, w: Święta Lipka: perła na pograniczu ziem, kultur i wyznań, red. A. Jacyniak, Warszawa 2008, s. 301-308; „Miejsca Święte”, (2008) nr 5 (137), s. 40-41; w: Królowa Polski o wielu obliczach. Wizerunki Matki Bożej koronowane przez Prymasa Tysiaclecia Stefana kardynała Wyszyńskiego, Częstochowa 2014, s. 204-207.

259. Zbąski Jan Stanisław, bp, Coronata Varmiae Felicitas In Infulato Principe Illvstrissimo, Celsissimo Et Reverendissimo Domino D. Joanne Stanislao a Sbaszyn Sbąski, Dei et Apostolicae Sedis Gratia Nuper Premisliensi, Nunc Varmiensi \& Sambiensi, Antistite In Primo Et Secvndo Secvndi Episcopatvs Aditv Plaudente Varmia, Et Per Encomiasticam Periphrasim Ab Applaudente Svae Illvstrissimae Celsitvdini Resseliensi Societatis Jesu Collegio Ad Posteros Transmissa Anno Faciati In Cvnis Dei Pontificis. M.DC.LXXXIX (1689), Brunsbergae 1689.

\section{Działalność kulturalna i naukowa}

260. Borzyszkowski Marian, Wystawa biblioteczna: Święta Lipka 1687-1987, „Studia Warmińskie”, 27 (1990) s. 325-329.

261. Bruździńska Jadwiga, Letnia olimpiada w Świętej Lipce 23-25 sierpnia 1948 r., w: Święta Lipka: perta na pograniczu ziem, kultur $i$ wyznań, red. A. Jacyniak, Warszawa 2008, s. 228-231.

262. Byczkowska-Sztaba Jolanta, Die werke von Isfrid Kayser im Repertoire der Jesuitenkapelle des Marienheiligtums zu Heiligelinde, w: U. Siegle, Oberschäbische Klostermusik im europäischen Kontext: Aleksander Szumski zum 70 Geburtstag, Frankfurt am Mein 2004.

263. Czechyra Łukasz, Umiejętności to za mało, „Gość Niedzielny”, 91 (2014) nr 19 (wkł. „Posłaniec Warmiński”). [Świętolipskie Wieczory Muzyczne]

264. Grześkiewicz Ewa, Kolejne warsztaty pisania ikon Grupy Agathos, „U stóp Świętolipskiej Matki", (2016) nr 6, s. 8-9.

265. Grześkiewicz Ewa, Warsztaty pisania ikon grupy Agathos, „U stóp Świętolipskiej Matki", (2017) nr 9, s. 5-6.

266. Grześkiewicz Ewa, Warsztaty pisania ikon oraz śpiewu gregoriańskiego i bizantyjskiego w świętolipskim sanktuarium, „U stóp Świętolipskiej Matki”, (2015) nr 3, s. 8-9.

267. Jacyniak Aleksander, 50-lecie rozpoczęcia nauki w podstawówce w Świętej Lipce, „U stóp Świętolipskiej Matki”, (2017) nr 7, s. 6-8.

268. Kluk Iwona Beata, Sesja naukowa „,Barok na Warmii”, Święta Lipka, Olsztyn 23-24 IX 1993 r., „Biuletyn Historii Sztuki”, 56 (1994) s. 326-327.

269. Kozłowski Krzysztof, Jak głos Pavarottiego, „Gość Niedzielny”, 90 (2013) nr 28 (wkł. „Posłaniec Warmiński”).

270. Kozłowski Krzysztof, Pod protekcją króla, „Gość Niedzielny”, 95 (2018) 
nr 12 (wkł. „Posłaniec Warmiński”), s. III. [Sympozjum popularnonaukowe w Świętej Lipce 17 marca 2018 roku]

271. Kozłowski Krzysztof, Wieczory z muzyka, „Gość Niedzielny”, 95 (2018) nr 27 (wkł. „Posłaniec Warmiński), s. II.

272. Marko Elżbieta, Szkoła prowadzona przez jezuitów w Reszlu, „U stóp Świętolipskiej Matki”, (2015) nr 2, s. 6-7.

273. Stępkowska Ewa, Nasz świętolipski chór, „U stóp Świętolipskiej Matki”, (2015) nr 2, s. 11-12.

274. Świat ikony u stóp Świętolipskiej Matki, „U stóp Świętolipskiej Matki”, (2015/2016) $\mathrm{nr}$ 4, s. 7-8.

275. Święta Lipka: perła na pograniczu ziem, kultur i wyznań, cz. 2, sympozjum popularnonaukowe 17 marca 2018 sobota, Święta Lipka 2018, ss. 4.

276. Wojtkowiak Józef, Prawykonanie światowe pierwszego oratorium Feliksa Nowowiejskiego „, Powrót syna marnotrawnego” op. 3, Olsztyn, Święta Lipka, 1993: wybrane problemy wykonawcze muzyki chóralnej na przykładzie dzieła, Olsztyn 1998, ss. 50.

277. Zadroga Danuta, Muzykalia świętolipskie przechowywane w Bibliotece Bobolanum w Warszawie, w: Święta Lipka: perła na pograniczu ziem, kultur $i$ wyznań, pod red. Aleksandra Jacyniaka, Warszawa 2008, s. 92-97.

278. Zielińska Lidia, Księgozbiór starodruków świętolipskich w Bibliotece Bobolanum w Warszawie, w: Święta Lipka: perła na pograniczu ziem, kultur $i$ wyznań, red. A. Jacyniak, Warszawa 2008, s. 88-97.

\section{Działalność społeczno-dobroczynna}

279. Bericht über die Friedrich-Wilhelms-Stiftung des Evangelischen Confirmandenhauses zu Bäslack in Ostpreußen, Rastenburg 1865.

280. Das Confirmandenhaus in Bäslack, w: Der Gustav-Adolfs-Bote für die Provinz Preußen, Bd 4, Königsberg 1863, s. 166-168.

281. Dritter Bericht über die Friedrich-Wilhelms-Stiftung des Evangelischen Confirmandenhaus zu Bäslack, Rastenburg 1878.

282. Jasiński Grzegorz, Ewangelickie zakłady opiekuńcze na Mazurach w drugiej połowie XIX wieku, „Gdański Rocznik Ewangelicki”, 7 (2013) s. 128. [Dom dla konfirmantów w Bezławkach]

283. Jodkowski Marek, Bezławki versus Swięta Lipka, czyli rzecz o budowie wiejskiego domu dla konfirmantów na pograniczu historycznej Warmii w XIX wieku, „Komunikaty Mazursko-Warmińskie”, (2017) nr 1, s. 79-90.

284. Kozłowski Krzysztof, Żyjemy jak na wsi, „Gość Niedzielny”, 90 (2013) nr 33 (wkł. „Posłaniec Warmiński”). [Działalność sióstr katarzynek w Świętej Lipce]

285. Szlendak Faustyna, Krusińska Letycja, Razem łatwiej, „U stóp Świętolipskiej Matki”, (2015) nr 2, s. 10-11. [Dom dla dziewcząt uzależnionych od alkoholu i narkotyków w Siemkach].

\section{Osoby związane ze Świętą Lipką}

286. Achremczyk Stanisław, Sadorski (Szadorski, Zadorski) Stefan (ok. 15841641), w: Polski Stownik Biograficzny, t. 34, Wrocław 1993, s. 289-290. 
287. Arszyński Marian, Mayer (Meier, Maijer, Majer, Mayer, Meier, Mejer) Mathias Johannes, w: Stownik Artystów Polskich i obcych w Polsce działajacych (zmartych przed 1966 r.), t. 5, red. J. Derwojed, Warszawa 1993, s. 236238.

288. Astachow-Kwiatkowska Dorota, Moja Mama: wspomnienie o śp. Krystynie Astachow, „U stóp Świętolipskiej Matki”, (2014/2015) nr 1, s. 13-15.

289. Boehm Jan, Feliks Nowowiejski: artysta $i$ wychowawca, Olsztyn 1985, ss. 210.

290. Boehm Jan, Feliks Nowowiejski: zarys biograficzny, Olsztyn 1968, ss. 129.

291. Borzyszkowski Marian, Kolberg Augustyn (1835-1909), w: Stownik biograficzny Kapituły Warmińskiej, red. J. Guzowski, Olsztyn 1996, s. 117.

292. Borzyszkowski Marian, Krause Antoni (1874-1945), w: Stownik biograficzny Kapituly Warmińskiej, red. J. Guzowski, Olsztyn 1996, s. 132.

293. Celińska Elżbieta, Jan Schwartz - kowal z Reszla, „Komunikaty Mazursko-Warmińskie", (1969) nr 3, s. 331-346.

294. Drema Vladas, Jerzy Ertli - budowniczy wileński, „Biuletyn Historii Sztuki", 42 (1980) nr 2, 141-144.

295. Eichhorn Albert, Geschichte der ermländischen Bischofswahlen, „Zeitschrift für die Geschichte und Alterstumskunde Ermlands", 1 (1860) s. 550-580. [Bp warmiński Michał Stefan Radziejowski]

296. Ertli (Ertly, Hertli) Jerzy (zm. ok. 1692), w: Stownik Biograficzny Warmii, Mazur i Powiśla od połowy XV wieku do 1945 roku, red. T. Oracki, Warszawa 1963, s. 72.

297. Fleischer Franz, Erinnerungen an Universitäts-Professor Kolberg, „Zeitschrift für die Geschichte und Alterstumskunde Ermlands", 20 (1919) s. 602617.

298. Fokt Iwona, Feliks Nowowiejski, Poznań 2016, ss. 410.

299. Gałka-Dudenko Krystyna, Wspomnienie o moim stryju śp. Aleksandrze Gat$k a$, ,U stóp Świętolipskiej Matki”, (2015) nr 2, s. 17-18.

300. Groeben Otto (1567-1649), w: Stownik Biograficzny Warmii, Mazur i Powiśla od połowy XV wieku do 1945 roku, red. T. Oracki, Warszawa 1963, s. 101-102.

301. Heydel Maria, Kolberg Peter (ok. 1665-po 1725), w: Stownik Artystów Polskich i obcych $w$ Polsce dziatajacych (zmartych przed 1966 r.), t. 4, red. J. Maurin-Białostocka, J. Derwojed, Wrocław-Warszawa-Kraków-Gdańsk-Łódź 1986, s. 64-66.

302. Heydel Maria, Pervanger (Perwanger) Christoph (zm. 1764 r.), w: Stownik Artystów Polskich i obcych w Polsce działajacych (zmarlych przed 1966 r.), t. 7, red. U. Makowska, Warszawa 2003, s. 32-34.

303. Heydel Maria, Peucker (Peichert, Peickert, Peiker, Peikert, Peuckert, Preike, Puchard) Christoph (Christian) (1662-1735), w: Stownik Artystów Polskich $i$ obcych $w$ Polsce dziatajacych (zmartych przed 1966 r.), t. 7, red. U. Makowska, Warszawa 2003, s. 60-62.

304. Kacprzycka-Domaradz Ela, Domaradz-Wilk Anna, Nasz Tata Piotr Doma$\mathrm{radz}$, „U stóp Świętolipskiej Matki”, (2016) nr 5, s. 16-17.

305. Karpowicz Mariusz, Polskie itinerarium Marcina Altomontego, „Rocznik Historii Sztuki”, 6 (1966) s. 97-159. 
306. Kawecki Roman, Kardynat Michat Stefan Radziejowski (1645-1705), Opole 2005, s. 34. [Wmurowanie kamienia węgielnego pod budowę kościoła w 1687 roku]

307. Klauza Gabriela, Feliks Nowowiejski: twórca wszechstronny, w: Non omnismoriar. Na tropach piękna: prace zadedykowane pamięci profesor Beaty Dabrowskiej dyrektora Instytutu Muzyki WA UMCS w latach 2005-2016, red. B. Pazur, Lublin 2017, s. 263-278.

308. Kolberg Josef, Domdechant Dr. Augustin Kolberg, „Zeitschrift für die Geschichte und Alterstumskunde Ermlands", 17 (1910) s. 464-477.

309. Kowalski Adam, 75 lat trudnego, ale i pięknego życia. Wywiad z pania Alina Szluma z Pieckowa, „U stóp Świętolipskiej Matki”, (2018) nr 10, s. 6-8.

310. Kozakiewicz Stefan, Ertli (hertli, Ertly) Jerzy (Jerzy, Jan?), (zm. 1696 lub 1697), w: Polski Stownik Biograficzny, t. 6, Kraków 1948, s. 292.

311. Łukaszewski Marcin Tadeusz, Bogu i Polsce na chwate, Narodowi ku pokrzepieniu, „Niedziela”, 44 (2016) s. 24-25. [Życiorys Feliksa Nowowiejskiego]

312. Majer Maciej (zm. 1737), w: Stownik Biograficzny Warmii, Mazur i Powiśla od połowy XV wieku do 1945 roku, red. T. Oracki, Warszawa 1963, s. 181.

313. Marko Elżbieta, Gerhard, nasz Tatuś, „U stóp Świętolipskiej Matki”, (2015/2016) nr 4, s. 17-19.

314. Obłąk Jan, Historia diecezji warmińskiej, Olsztyn 1959, s. 139, 148. [Stefan Sadorski i Tomasz Klage]

315. Obłąk Jan, Jerzy Ertli, budowniczy Świętej Lipki, „Rocznik Olsztyński”, 3 (1960) s. 115-131.

316. Olbert Joanna, Feliks Nowowiejski: wielki kompozytor i patriota, „Seminare", 18 (2002) s. 627-635.

317. Poplatek Jan, Engell Michat (XVII-XVIII w.), w: Polski Stownik Biograficzny, t. 6, Kraków 1948, s. 271-272.

318. Przeracki Jerzy, Artyści działajacy na Warmii w XVIII wieku: Krzysztof Peucker, Jan Chrystian Schmidt, Chrystian Bernard Schmidt, Krzysztof Sand, Jan Witt, Jan Ignacy Witt, Jan Antoni Frey, Piotr Andrzej Kolberg i Józef Joachim Korzeniewski, „Komunikaty Mazursko-Warmińskie”, (2011) nr 3, s. 441-499.

319. Przybylski Tadeusz, Nowowiejski Feliks (1877-1946), w: Polski Stownik Biograficzny, t. 23, Wrocław-Warszawa-Kraków-Gdańsk 1978, s. 401-403.

320. Rachuba Andrzej, Radziejowski Augustyn Michat Stefan h. Junosza (16451705), w: Polski Słownik Biograficzny, t. 30, Wrocław-Warszawa-Kraków-Gdańsk-Łódź 1987, s. 66-76.

321. Rzempołuch Andrzej, Krzysztof Perwanger (1708-1764): działalność artystyczna na Warmii i w Prusach Królewskich, „Rocznik Olsztyński”, 17 (1997) s. 253-291.

322. Strumiński Józef, Krzysztof Perwanger - rzeźbiarz z Tolkmicka, „Komunikaty Mazursko-Warmińskie", (1969) nr 4, s. 581-588.

323. Szorc Alojzy, Stefan Sadorski (1581-1640) - fundator Świętej Lipki, cz. 1, „Komunikaty Mazursko-Warmińskie”, 38 (1994) nr 4, s. 396-414.

324. Szorc Alojzy, Stefan Sadorski (1581-1640). Fundator Świętej Lipki, Olsztyn 1996, ss. 141. 
325. Szwagrzyk Józef, Groeben (Gröben), von der Otto z Kobbern k/Frydladu (zm. 1649), w: Polski Stownik Biograficzny, t. 8, Wrocław-Kraków-Warszawa 1959-1960, s. 624.

326. Wróblewska Kamila, Piotr Kolberg, „Biuletyn Historii Sztuki” 32 (1970), s. 397-401.

327. Wróblewska Kamila, Piotr Kolberg - malarz warmiński z końca XVII i poczatku XVIII stulecia, „Komunikaty Mazursko-Warmińskie”, (1969) nr 3, s. 295-300.

328. Zadorski (Szadurski, Sadorski) Stefan (ok. 1584-1641), w: Stownik Biograficzny Warmii, Mazur i Powiśla od połowy XV wieku do 1945 roku, red. T. Oracki, Warszawa 1963, s. 313.

\section{Innowiercy}

329. Bericht über die Friedrich-Wilhelms-Stiftung des Evangelischen Confirmandenhauses zu Bäslack in Ostpreußen, Rastenburg 1865.

330. Das Confirmandenhaus in Bäslack, w: Der Gustav-Adolfs-Bote für die Provinz Preußen, Bd 4, Königsberg 1863, s. 166-168.

331. Dritter Bericht über die Friedrich-Wilhelms-Stiftung des Evangelischen Confirmandenhaus zu Bäslack, Rastenburg 1878.

332. Hochleitner Janusz, Ewangeliccy pielgrzymi w Świętej Lipce. Z dziejów pogranicza warmińsko-mazurskiego, „Mrągowskie Studia Humanistyczne”, 2 (2000) s. 31-39.

333. Hochleitner Janusz, „Katolickość” pruskich ewangelików na przykładzie ich udziału w pielgrzymkach do Świętej Lipki, „Rocznik Mazurski”, 4 (1999) s. $45-52$.

334. Jasiński Grzegorz, Ewangelickie zakłady opiekuńcze na Mazurach w drugiej połowie XIX wieku, „Gdański Rocznik Ewangelicki”, 7 (2013) s. 128.

335. Jodkowski Marek, Bezławki versus Święta Lipka, czyli rzecz o budowie wiejskiego domu dla konfirmantów na pograniczu historycznej Warmii w XIX wieku, „Komunikaty Mazursko-Warmińskie”, (2017) nr 1, s. 79-90.

336. Katholische Bräuche im masurischen Ostpreussen, „Ermländisches Kirchenblatt", (1938) nr 46, s. 660.

337. Nowak Władysław, Kult maryjny wśród polskich protestantów na Mazurach, „Studia i Dokumenty Ekumeniczne”, (1983) nr 3, s. 9-26.

338. Nowak Władysław, Sanktuarium NMP w Świętej Lipce a kult maryjny wśród protestantów na Mazurach, „Przegląd Powszechny”, (1983) nr 5/6, s. $217-$ 230.

\section{Albumy i przewodniki}

339. Bałdowski Jan, Święta Lipka, Warszawa 1985, ss. 36; wyd. 2, Warszawa 1987, ss. 36; wyd. 3, Warszawa 1990, ss. 36.

340. Do Ciebie Matko idziemy. Sanktuaria maryjne w Polsce, red. J. Soszyńska, Gdańsk 1999, ss. 478.

341. Dziadek Irena, Dziadek Henryk, Święta Lipka. Przewodnik, Kętrzyn 1997, ss. 29; Kętrzyn 2001, ss. 43; Kętrzyn 2007, ss. 44; Kętrzyn 2013, ss. 44; Kętrzyn 2015, ss. 44; Kętrzyn 2016, ss. 32. 
342. Dziadek Irena, Dziadek Henryk, Heiligelinde. Święta Lipka. Reiseführer, Kętrzyn 2016, ss. 32.

343. Fedczak Agnieszka, Święta Lipka. Przewodnik, Kętrzyn 2003, ss. 48.

344. Jankowski Grzegorz, Sanktuaria polskie: Jasna Góra, Niepokalanów, Kalwaria Zebrzydowska, Łagiewniki, Licheń, Góra św. Anny, Święta Lipka, Piekary Ślaskie, Gietrzwałd, Tuchów, Warszawa 2005, ss. 128.

345. Kot Roman, Miejsca, gdzie niebo spotyka się z ziemia, Warszawa 2014, ss. 154.

346. Królowa narodu, cz. 3: Wybrane sanktuaria maryjne diecezji warmińskiej: Stoczek Warmiński, Gietrzwałd, Święta Lipka oraz Sanktuarium Maryjne Matki Bożej Wędrowców w Neviges, „Pocieszycielki Strapionych” w Kevelaer w Niemczech, a także Matki Bożej Panny Ubogich w Banneaux w Belgii, pod red. Arno Giese, Pelplin 2007, ss. 316.

347. Kubajak Anna, Najstawniejsze sanktuaria Polski, Kraków 2001, ss. 134.

348. Malicki Edward, Polskie sanktuaria maryjne, Kraków 2006, s. 135.

349. Paszenda Jerzy, Heiligelinde. Begleiter bei der Besichtigung, Heiligelinde 1995.

350. Paszenda Jerzy, Święta Lipka: bazylika mniejsza, Olsztyn 2010, ss. 95.

351. Paszenda Jerzy, Stachurski Andrzej, Święta Lipka (ehem. Heiligelinde), Olsztyn 2005, ss. 79.

352. Paszenda Jerzy, Święta Lipka. Przewodnik, Gdańsk 1984, ss. 26; -wyd. 2, Gdańsk 1987, ss. 26.

353. Paszenda Jerzy, Święta Lipka. Przewodnik, Wrocław-Kraków 2001, ss. 47; wyd. nowe, Wrocław 2008, ss. 72; wyd. nowe, Wrocław 2009, ss. 72; wyd. nowe, Wrocław 2011, ss. 71; wyd. nowe, Wrocław 2013, ss. 71.

354. Połubiński Robert, Przewodnik po Świętej Lipce. Wydanie specjalne: 50 rocznica koronacji obrazu Matki Bożej Świętolipskiej, Kętrzyn 2018, ss. 40.

355. Puciato Czesław, Święta Lipka, Kętrzyn, Olsztyn i okolice, Kętrzyn 2001, ss. 48.

356. Puciato Czesław, Puciato Zofia, Święta Lipka, Kętrzyn, Giertoż, Olsztyn, Reszel i okolice, Kętrzyn 2013, ss. 64.

357. Rzempołuch Andrzej, Święta Lipka. Przewodnik, Olsztyn 1991.

358. Siemiński Stanisław, Heiligelinde und andere Sanktuarien des Erzbistums Ermland, Kętrzyn 2013, ss. 56.

359. Siemiński Stanisław, Święta Lipka, Wilczy Szaniec i Mazury Pótnocne, Kętrzyn 1998, ss. 128.

360. Swięta Lipka, fot. Andrzej Artur Mroczek, Warszawa [b.d.wyd.], s. 16.

361. Święta Lipka/Heiligelinde, w: Kościoły i kaplice Archidiecezji Warmińskiej, t. 2, pod red. Bronisława Magdziarza, Olsztyn 1999, s. 12-13, 80-85.

362. Tarasewicz Hanna, Tarasewicz Stanisław, Heiligelinde. llustrierter Prospekt, Bartoszyce 2005, ss. 48.

363. Tarasewicz Hanna, Tarasewicz Stanisław, Swieta Lipka (Saint Tilleul). Guide illustré, Bartoszyce 2005, ss. 48.

364. Woronowicz Alicja, Heiligelinde. Reisefuhrer [ubers. Teresa Demuth-Kaiser], Kętrzyn 2006, ss. 44; Kętrzyn 2012, ss. 47. 
365. Woronowicz Alicja, Święta Lipka. Przewodnik, Kętrzyn 2016, ss. 48.

366. Woronowicz Alicja, Święta Lipka. Sanktuarium maryjne, Kętrzyn 2017, ss. 31.

367. Woronowicz Alicja, Šventa Liepelè, Kętrzyn 2010, ss. 43.

368. Woronowicz Alicja, Szymański Grzegorz (fot.), Święta Lipka. Przewodnik, Kętrzyn 2001, ss. 42; Kętrzyn 2003, ss. 42; Kętrzyn 2011, ss. 47.

369. Zduniak Agnieszka, Heiligelinde Reisefuhrer, Kętrzyn 2001, ss. 48; Kętrzyn 2002, ss. 48; Kętrzyn 2003, ss. 48.

370. Zduniak Agnieszka, Święta Lipka. Przewodnik, Kętrzyn 2001, ss. 48; Kętrzyn 2003, ss. 48.

371. Zduniak Agnieszka, Ulewicz Andrzej, Stachurski Andrzej (fot.), Zduniak Jan (fot.), Święta Lipka, Olsztyn 1997, s. 47.

372. Zduniak Jan, Święta Lipka, Kętrzyn, Wilczy Szaniec, Twierdza Giżycka: ilustrowany przewodnik, Kętrzyn 2000, ss. 96; Kętrzyn 2003, ss. 96.

373. Z dawna Polski Tyś Królową: przewodnik po sanktuariach maryjnych. Koronowane wizerunki Matki Bożej 1717-1983, red. P. Anzulewicz, Szymanów 1983, s. 463-466.

\section{Miscellanea}

374. Behlau Ulrich, Verhandlungen über eine Berufung der Redemptoristen nach Springborn und Heilige Linde 1861, ,Zeitschrift für die Geschichte und Altertumskunde Ermlands", 31/32 (1967/1968) s. 321-358.

375. (bm), W Świętej Lipce zakatowano człowieka, „Gazeta Kętrzyńska” 1 (1990) nr 8, s. 1. [Sprawa brutalnego pobicia we wsi Swięta Lipka, 29 października 1990 roku]

376. Bochenek Małgorzata, Częstochowa Pólnocy, „Nasz Dziennik”, (2018) nr 143 (6197).

377. Bober Andrzej, Święta Lipka, ośrodek wiary i polskości na Warmii i Mazurach, „Kalendarz Serca Jezusowego na 1948 rok”, Kraków 1947, s. 58-65.

378. Bober Andrzej, Taniec imion, „Tygodnik Powszechny”, (1947) nr 44, s. 12.

379. Dąbrowska Czesława, Genius loci, czyli duch miejsca. Święta Lipka w poezji, „U stóp Świętolipskiej Matki”, (2017) nr 8, s. 8-11.

380. Klimek Robert, Ślady średniowiecznej granicy Warmii między Reszlem a Święta Lipka, „Studia Geohistorica”, 4 (2016) s. 40-52.

381. Kurkowski Franciszek, Jakie treści kryja się $w$ dwu pierwszych z odnalezionych egzemplarzy ,Wiadomości Parafialnych” z lat 1934-1936?, „U stóp Świętolipskiej Matki”, (2014-2015) nr 1, s. 4/5; cz. 2, „U stóp Świętolipskiej Matki", (2015) nr 3, s. 2-3.

382. Mętlewicz Jan, O Świętej Lipce (Heilige Linde), „Pamiętnik Religijno-Moralny", 24 (1853), nr 5, s. 473-488.

383. Nowak Władysław, Świętolipska Pani Krainy Mazur - Matka Jedności chrześcijan. Kalendarz Maryjny, Olsztyn 1982, s. 121-128.

384. Paszenda Jerzy, Sanktuarium świętolipskie, „Przegląd Powszechny”, (1987) nr 5, s. 220-230.

385. Stadtmüller Ewa, Święta Lipka, Sandomierz 2008, ss. 23; Sandomierz 2013, ss. 23. 
386. Szorc Alojzy, Diaspora diecezji warmińskiej za biskupa Andrzeja Chryzostoma Załuskiego (1698-1711), ,, Studia Warmińskie”, 3 (1966) s. 65-88.

387. Szydłowska Joanna, Święta Lipka jako źródło inspiracji literackich, „Rocznik Olsztyński”, 17 (1997) s. 167-181.

388. Zawitkowski Józef, Ty jesteś taka na obrazach śliczna, „Nasz Dziennik”, (2018) nr 105 (5858).

\section{BIBLIOGRAFIA}

Achremczyk Stanisław, Znaczenie Świętej Lipki w Rzeczpospolitej szlacheckiej, w: Święta Lipka: perła na pograniczu ziem, kultur i wyznań, red. A. Jacyniak, Warszawa 2008, s. 98-117.

Borzyszkowski Marian, Święta Lipka w latach 1920-1940, „Studia Warmińskie”, 32 (1995) s. 103-116.

Buszko Eliza, Problemy konserwatorskie sanktuarium w Świętej Lipce, w: Święta Lipka: perła na pograniczu ziem, kultur i wyznań, red. A. Jacyniak, Warszawa 2008, s. 176-198.

Czapski Michał, Zabezpieczenie krużganków w Świętej Lipce, „Inżynieria i Budownictwo" 16 (1959) nr 1, s. 1-6.

Ciaritius Michael Fridericus, B. V. M. Lindensis. Vetustissimum et religiossimum in Prussia Sacellum Beatis-simae Virginis Mariae sacrum, prodigiis divinis clarissimum, Brunsbergae 1626.

Clagius Thomas, Linda Mariana sive de B. Virgine Lindensi libri V, Coloniae 1659.

Hochleitner Janusz, Przydrożne pomniki kultu religijnego Świętej Lipki i okolic, „Studia Angerburgica", 2 (2006) s. 78-91.

Hochleitner Jnusz, Religijność Mazurów manifestowana w Świętej Lipce (XVI-XX w.), w: Mniejszość i większość. Relacje kulturowe na pograniczach, cz. 1, red. Paweł Pietnoczka, Olsztyn 2016, s. 175-192.

Jacyniak Aleksander, Chcę stużyć Matce Bożej Świętolipskiej, „Nasza Arka”, (2018) nr 5 (209), s. 13.

Kolberg Augustyn, Geschichte der Heiligelinde, „Zeitschrift für die Geschichte und Altertumskunde Ermlands", 1866, Bd 3, s. 28-138; 435-520.

Kopiczko Andrzej, Władze partyjno-państwowe wobec koronacji obrazu Matki Bożej w Świętej Lipce, w: Święta Lipka: perta na pograniczu ziem, kultur $i$ wyznań, red. A. Jacyniak, Warszawa 2008, s. 245-300.

Lühr Georg, Die Jesuiten von Rösel und Heiligelinde, „Zeitschrift für die Geschichte und Alter-tumskunde Ermlands", 20 (1919) nr 20, s. 753-800.

Obłąk Jan, Święta Lipka, Olsztyn 1975; wyd. 2, Olsztyn 1982.

Ropiak Sławomir, Pieśni świętolipskie, w: Święta Lipka: perła na pograniczu ziem, kultur i wyznań, red. A. Jacyniak, Warszawa 2008, s. 147-166.

Sulima Rafał, Organy świętolipskie, w: Święta Lipka: perła na pograniczu ziem, kultur i wyznań, red. A. Jacyniak, Warszawa 2008, s. 131-146.

Ulbrich Anton, Die Wallfahrtskirche in Heiligelinde. Ein Beitrag zur Kunstgeschichte des XVII. und XVIII. Jahrhunderts in Ostpreussen, Strassburg 1901.

Wanat-Zakrzewska Maria, Konserwacja rzeźby kamiennej barokowego ko-ścioła w Świętej Lipce w latach 1982-1987, „Rocznik Olsztyński”, 17 (1997) s. 125-141.

Zielińska Lidia, Księgozbiór starodruków świętolipskich w Bibliotece Bobolanum w Warszawie, w: Święta Lipka: perła na pograniczu ziem, kultur i wyznań, red. A. Jacyniak, Warszawa 2008, s. 88-97. 


\section{Indeks osób i nazw geograficznych}

\section{$\mathbf{A}$}

Achremczyk Stanistaw 22, 23, 286

Gorgoniusz Ageison SJ 119

Altomonte Marcin 305

Aniela od św. Józefa, bł. 250

Antoniewicz Józef SJ 121

Anzulewicz Piotr 373

Arszyński Marian 108, 287

Astachow Krystyna 288

Astachow-Kwiatkowska Dorota 288

Aucepius Teodor SJ 122

\section{B}

Babicka Maria 70

Bakhita Józefina, bł. 250

Balter Lucjan 24

Batdowski Jan 339

Banneaux 346

Baracz Sadok 154

Barcja 69

Barczewo 219, 224

Barczewski Walenty 226

Bartlewicz Jan 115

Bartoszyce 362, 363

Belgia 346

Bezławecki Dwór 44

Bezławki (Bäslack) 27, 37, 48, 49, 50, 54, 69, 279, 280, 281, 282, 283, 329, 330, $331,334,335$

Behlau Ulrich 374

Białostocka-Maurin Jolanta 301

Bielawny Krzysztof 177, 178

Birch-Hirschfeld Anneliese 179

Bitrowicz Bronisław SJ 129

Bober Andrzej 25, 377, 378

Bochenek Matgorzata 160, 376

Boehm Jan 289, 290

Bogdanowski Janusz 72

Borzyszkowski Marian 26, 227, 260, 291, 292

Bosko Janina 73

Bötticher Adolf 74

Braniewo (Braunsberg) 108, 147, 161, $163,164,165,170,184,251,252,253$
Brillowski Wojciech 27

Bruski Ireneusz Stanisław 28, 180

Bruździńska Jadwiga 181, 261

Brzostek Krzysztof 203

Buchholz Franz 104

Bulanda Edward 116

Buszko Eliza 75

Byczkowska-Sztaba Jolanta 262

C

Casparini Adam Horatio 110

Celińska Elżbieta 293

Chlebowski Bronistaw 18

Chojnowski Zbigniew 29, 76

Chorzów 155

Chwalęcin 167

Chyra Maciej „Łoś” 248

Ciaritius Michael Fridericus 161

Cieszyński Klaus Peter SJ 138

Cieślak Anna 28

Costa Aleksandra Maria, bł. 250

Czapliński Konrad Kazimierz 5, 30, 155

Czapski Michat 77

Czechyra Lukasz 183, 263

Częstochowa 258, 376

D

Daleczko Władysław SJ 117, 151

Danieluk Robert 31

Darowski Roman 119

Dąrowska Beata 307

Dąrowska Czestawa 379

Dejnowa (jezioro) 65

DEM 229

Derwojed Janusz 287, 301

Domaradz Piotr 304

Domaradz-Wilk Anna 304

Drema Vladas 294

Drzazga Józef, bp warm. 230, 231

Dziadek Henryk 341, 342

Dziadek Irena 341, 342

Dzwonkowski Roman 120 
E

Eichhorn Albert 295

Elbląg 106 - elbląskie województwo 108

Ełk 203

Engell (Engel) Michał 118, 317

Ertli Jerzy 294, 296, 310, 315

F

Faryna-Paszkiewicz Hanna 6

Fedczak Agnieszka 343

Fleischer Franz 297

Fokt Iwona 298

Frankfurt nad Menem 262

Frey Jan Antoni 318

Fridrich Alojzy 156

Frombork 108

Frydląd 325

\section{G}

Gać Jan 32

Gałka Aleksander 299

Gałka-Dudenko Krystyna 299

Gattorno Anna, bł. 250

Gdańsk 27, 37, 54, 69, 134, 193, 218, 301, 319, 320, 340, 352

Geppert Zygmunt SJ 131

Gesturi Mikołaj, bł. 250

Gierłoż 356

Giese Arno 346

Gietrzwałd 35, 344, 346

Gigilewicz Edward 4

Giżycko 372

Gołos Jerzy 106

Góra Świętej Anny 344

Górzyński Józef, abp warm. 245

Groeben Otto 300, 325

Gruszka-Zych Barbara 33

Grzebień Ludwik 1, 13, 121, 122, 123, $124,125,126,127,150$

Grześkiewicz Ewa 264, 265, 266

Gustaw Adolf, król Szwecji 280, 330

Guzowski Jan 291, 292

\section{H}

Harwardt B. 128

Helik Adrian 185

Heydel Maria 301, 302, 303

Hochleitner Janusz 78, 79, 186, 187, 188, 189, 190, 332, 333
J

Jacyniak Aleksander 23, 24, 29, 31, 43, 75, $82,107,114,115,129,130,131,132$, $143,148,157,166,172,175,181,202$, $209,211,225,232,233,234,235,236$, 237, 242, 249, 258, 261, 267, 277, 278

Jagla Jowita 167

Jan Pawet II, papież 238

Janca Jan 110

Jankowski Grzegorz 344

Jasiński Grzegorz 282, 334

Jasiński Janusz 191

Jasna Góra 344

Jelińska Elżbieta 80, 81

Jodelis Wincenty 133

Jodkowski Marek 283, 335

\section{K}

Kacprzycka-Domaradz Ela 304

Kaczorowski Andrzej 34

Kaczorowski Robert 192, 193, 218

Kalwaria Zebrzydowska 344

Katowice 5, 30, 155

Karpowicz Mariusz 305

Kawecki Roman 306

Kevelaer 346

Kepkowicz Agnieszka 82

Kętrzyn (Rastenburg) 47, 83, 279, 281, $329,331,341,342,343,354,355,356$, $358,359,364,365,366,367,368,369$, 370, 372

Kętrzyński Wojciech 239, 240

Kita Jarosław 186

Klafki Leo 194

Klage (Clagius) Thomas 123, 139, 162, $165,182,314$

Klauza Gabriela 307

Klewno 46

Klimek Robert 35, 380

Kluk Iwona Beata 268

Koch Ludwig 3

Kochanowicz Jerzy 220

Kolberg Augustyn 36, 291, 297, 308

Kolberg Peter 301, 318, 326, 327

Kolberg Josef 308

Kolonia (Köln, Colonia) 110, 162, 182

Koperkiewicz Arkadiusz 27, 37, 54, 69

Kopiczko Andrzej 219, 241, 242

Korowaj Tadeusz 38, 39, 40, 41, 42, 43, $44,45,46,83$ 
Korybut-Marciniak Maria 186

Kot Roman 345

Korzeniewski Józef Joachim 318

Kowalewska Magdalena 195

Kowalski Adam 309

Kozakiewicz Stefan 310

Kozłowski Krzysztof 47, 168, 196, 243, 244, 245, 246, 269, 270, 271, 284

Kraków (Cracovia) 1, 9, 11, 13, 17, 57, $61,150,153,156,158,174,176,220$, $301,310,317,319,320,325,347,348$, 353, 377

Krasowska Helena 169

Krause Antoni 292

Krollmann Christian 109

Królewiec (Königsberg) 74, 100, 105, 110, 280, 330

Krusińska Letycja 285

Kubajak Anna 347

Kuprjaniuk Stanisław 85

Kurkowski Franciszek 381

Kutzner Marian 108

Kwiatkowski Krzysztof 48, 4950

$\mathbf{L}$

Lembruk (Langenbrück) 45, 64

Lentini Dominika, bł. 250

Lenz Edmund 135

Licheń 344

Lieder Franciszek 197, 247

Lisińska Halina 97

Litwa 13,150

Lizała Aleksy SJ 116, 136, 142, 143

Lublin 4, 120, 307

lucy 198

Lühr Georg 137

Lwów 154

\section{$\mathbf{L}$}

Łagiewniki (Kraków) 344

Lęawski Krzysztof 248

Łódź 181, 186, 301

Łukaszewski Marcin Tadeusz 311

Łukawski Jan SJ 148

\section{M}

Mach Józef SJ 141

Magdeburg 109

Magdziarz Bronistaw 84, 361

Makowska Urszula 302, 303
Malicki Edward 348

Man[n]heim 2, 7

Maria od Męki Pańskiej, bł. 250

Marko Elżbieta 52, 86, 221, 272, 313

Matczak Bartłomiej 199, 200

Mayer (Majer, Mejer) Maciej Jan 96, 287, 312

Mazury (Masuren, Masuria) 82, 118, 192, 201, 205, 212, 226, 282, 296, 300, 312, $328,334,337,338,359,377,383$

Mętlewicz Jan 382

Milewski Zygmunt 53

Miłobędzki Adam 87

Mitura A. 201

Mogas Anna, bł. 250

Mosengel Jan Jozue 106, 109, 110

Motyliński Janusz SJ 134

Möller Bartłomiej SJ 144

Mrągowo 198

Mroczek Andrzej Artur 360

Mróz Franciszek 166, 202

Musialik Wanda 138

Münster 92

Myszor Jerzy 138, 145

Myszyniec 206

\section{$\mathbf{N}$}

Nahzer Michał SJ 124

Natoński Bronisław 139

Neviges 346

Niemcy 346

Niepokalanów 344

Niewodnik 66

Nowak Władysław 203, 204, 205, 249, 337, 338, 383

Nowakiewicz Tomasz 54

Nowakowski Edward [Ks. Wacław z Sulgostowa] 158

Nowowiejski Feliks 219, 224, 276, 289, 290, 298, 307, 311, 316, 319

\section{$\mathbf{O}$}

Obłak Jan, bp warm. 55, 222, 314, 315

Olbert Joanna 316

Olsztyn 55, 60, 84, 85, 90, 173, 175, 177, $178,180,186,188,189,190,192,197$, $216,219,226,239,241,247,268,276$, 289, 290, 291, 292, 314, 324, 355, 356, $357,361,371,383$

Opole 248 
Oracki Tadeusz 118, 296, 300, 312, 328

Orneta 108

Ostrowski Janusz, bp 183

\section{$\mathbf{P}$}

Paderborn 3

Paluszkiewicz Felicjan 117, 136

Parda Szymon Jan 56

Pasieczny Robert 6

Pastuszka Jan SJ 146

Paszenda Jerzy 4, 57, 58, 59, 60, 61, 88, 89, 90, 142, 143, 144, 172, 173, 206, $207,349,350,351,352,353,354$

Pavarotti Luciano 269

Paweł VI, papież, bł. 230

Paziewski Michat 145

Pazur Beata 307

Perwanger Krzysztof (Christoph) 93, 102, 302, 321, 322

Peucker Krzysztof (Christoph) 303, 318

Pieckowo 38, 39, 309

Piekary Śląskie 344

Pietnoczka Pawet 188

Pilec 38, 65, 66

Piskorek Julian 146

Pohls J. 62

Poklewski Józef 63, 91

Polak Grzegorz 19

Polska 13, 150, 153, 154, 156, 158

Połubiński Robert 64, 65, 250, 354

Poplatek Jan 317

Poschmann Adolf 147

Pomorze 191

Powiśle (region w płn. Polsce) 118, 296, $300,312,328$

Poznań 34, 63, 91, 298

Prusy (Preussen) 49, 54, 110, 161, 176, 203, 280

Prusy Królewskie 321

Prusy Książęce 91

Prusy Wschodnie (Ostpreussen) 74, 92, $100,101,110,213,240,279,329,336$

Przeracki Jerzy 318

Przybylski Tadeusz 319

Przydatek Kazimierz 209, 210

Przytocka Maria 206

Puciato Czesław 355, 356

Puciato Zofia 356

Pudwąi 38, 39, 40
$\mathbf{R}$

Rachuba Andrzej 320

Radziejowski Michał Stefan, kard. 295, 306, 320

Ramty 42

Reifferscheid Gerhard 92

Renkewitz Werner 110

Reszel (Rössel) 42, 78, 86, 137, 147, 272, 293, 356, 380

Reuther Hans 67

Rochel (Rochell) Jan SJ 125

Rondomańska Zofia 223

Ropiak Stawomir 211

Ruiz de los Panos y Angel Piotr, bł. 250

Rzempotuch Andrzej 93, 321, 357

$\mathbf{S}$

Sadorski Stefan 286, 314, 323, 324, 328

Sand Krzysztof 318

Sandomierz 385

Schill Grzegorz SJ 126

Schmidt Chrystian Bernard 318

Schmidt Jan Chrystian 318

Schulz Heribert SJ 128, 132

Schwartz Jan 293

Seroczyński Franciszek SJ 115

Sianko Józef 111, 112

Siegle U. 262

Siemiński Stanisław 358, 359

Siemki 38, 285

Smoliński Mariusz 95

Smulikowska Ewa 113

Soszyńska Janina 340

Sroka Bronisław SJ 145

Stachurski Andrzej 90, 351, 371

Stadtmüller Ewa 385

Stępowska Ewa 273

Stempel Maciej SJ 127

Stoczek [Warmiński] 346

Stumiński Józef 322

Strzyżewski Waldemar SJ 107, 130

Sulima Rafat 114

Stoga Andrzej 96, 97, 98

Szatrawski Krzysztof Dariusz 219, 224

Szczepański Seweryn 69

Szembek Krzysztof Andrzej Jan, bp warm. 251, 252

Szlendak Faustyna 285

Szluma Alina 309

Szorc Alojzy 323, 324, 386 
Szumski Aleksander 262

Szwagrzyk Józef 325

Szydłowska Joanna 387

Szymanów 373

Szymański Grzegorz 368

Szymański Stanisław 148, 174, 175

Ś

Święta Lipka (Heiligelinde, Linda Mariana) $1-378$

\section{$\mathbf{T}$}

Tarasewicz Hanna 362, 363

Tarasewicz Stanisław 362, 363

Terlecki Max 106

Tolkmicko 322

Toruń 63

Trochimczak Monika 254

Tuchów 344

\section{V}

Vetulani Cecylia 99

$\mathbf{U}$

Ulbrich Anton 100, 101

Ulewicz Andrzej 371

\section{W}

Wagner Arkadiusz 102

Walewski Władystaw 18

Wanat-Zakrzewska Maria 103

Wandali Mamert 213

Wanguty 38, 41

Warszawa $6,8,10,12,14,15,16,18,19$, $20,21,23,24,29,31,43,63,75,82,87$, 91, 97, 106, 107, 108, 114, 115, 117, $118,121,122,123,124,125,126,127$, $129,130,131,136,138,143,145,148$, 157, 171, 172, 181, 201, 202, 209, 211, $212,225,242,, 249,258,261,277,278$, 287, 296, 300, 301, 302, 303, 312, 319, $320,325,328,339,344,345,360$

Warmia (Ermland) 70, 82, 85, 97, 118, 137, 179, 184, 187, 189, 192, 197, 213, $217,247,252,253,295,297,259,268$, 283, 296, 300, 308, 312, 318, 321, 328, $335,358,374,377,380$

Wasilewski Czesław 255
Wilczy Szaniec (Wolfsschanze) 359, 372

Witt Jan 318

Witt Jan Ignacy 318

Wojtkowiak Józef 276

Wojtyła Karol, kard. 195, 209, 210, 214

Wołodkowicz Kazimierz 176

Wołoszyn Mieczysław SJ 149, 152

Woronowicz Alicja 364, 365, 366, 367, 368

Wrocław 113, 139, 286, 302, 319, 320, 325,353

Wróblewska Kamila 326, 327

Wyczawski Hieronim Eugeniusz 122, 123, $124,125,126,127$

Wyszyński Stefan, kard. 258

$\mathbf{X}$

xps 215

\section{$\mathbf{Z}$}

Zadroga Danuta 225, 277

Załęski Stanisław 153

Załuski Andrzej Chryzostom, bp warm. 386

Zawitkowski Józef, bp 388

Ząbek Antoni SJ 120, 133, 135, 140

Zbąski Jan Stanisław, bp warm. 259

Zduniak Agnieszka 369, 370, 371

Zduniak Jan 371, 372

Zielińska Lidia 278

Zientara-Malewska Maria 216, 217

ZSRS 120 


\title{
BIBLIOGRAPHY OF THE SANCTUARY OF THE MOTHER OF CHRISTIAN UNITY IN ŚWIĘTA LIPKA FOR THE YEARS 1618-2018
}

\begin{abstract}
Summary
The Marian sanctuary in Święta Lipka, in the Masurian Lakeland macroregion, is one of the most famous sacred places in Poland. Pilgrims from Poland and from abroad have been coming here since the Middle Ages. People pray to Our Lady of the miraculous painting. They also listen to music that is played on a baroque pipe organ. In 2018, the sanctuary celebrated important jubilees: the 400th anniversary of the protection of the Polish king Sigismund III Waza over the sanctuary; the 125th anniversary of the music school graduation of the composer Feliks Nowowiejski; the 50th anniversary of the crowning of the image of Our Lady by the Polish Primate, Cardinal Stefan Wyszyński and the Archbishop of Kraków, Cardinal Karol Wojtyła. The festive jubilee gave the opportunity to summarize scientific research on the church and monastery of the Jesuits. The author of the bibliography presents what we already know about the sanctuary, and also suggests research areas that have not yet been analyzed by historians.
\end{abstract}

Key words: Święta Lipka, The Jesuits, The Marian cult, bibliography, historical research. 